\title{
Advances in Understanding the Complex Mechanisms of DNA Interstrand Cross-Link Repair
}

\author{
Cheryl Clauson ${ }^{1}$, Orlando D. Schärer ${ }^{2}$, and Laura Niedernhofer ${ }^{1,3}$ \\ ${ }^{1}$ Department of Microbiology and Molecular Genetics, The University of Pittsburgh, Pittsburgh, \\ Pennsylvania 15219 \\ ${ }^{2}$ Department of Pharmacological Sciences and Department of Chemistry, Stony Brook University, \\ Stony Brook, New York 11794-3400 \\ Correspondence: Iniedern@scripps.edu
}

DNA interstrand cross-links (ICLs) are lesions caused by a variety of endogenous metabolites, environmental exposures, and cancer chemotherapeutic agents that have two reactive groups. The common feature of these diverse lesions is that two nucleotides on opposite strands are covalently joined. ICLs prevent the separation of two DNA strands and therefore essential cellular processes including DNA replication and transcription. ICLs are mainly detected in S phase when a replication fork stalls at an ICL. Damage signaling and repair of ICLs are promoted by the Fanconi anemia pathway and numerous posttranslational modifications of DNA repair and chromatin structural proteins. ICLs are also detected and repaired in nonreplicating cells, although the mechanism is less clear. A unique feature of ICL repair is that both strands of DNA must be incised to completely remove the lesion. This is accomplished in sequential steps to prevent creating multiple double-strand breaks. Unhooking of an ICL from one strand is followed by translesion synthesis to fill the gap and create an intact duplex DNA, harboring a remnant of the ICL. Removal of the lesion from the second strand is likely accomplished by nucleotide excision repair. Inadequate repair of ICLs is particularly detrimental to rapidly dividing cells, explaining the bone marrow failure characteristic of Fanconi anemia and why cross-linking agents are efficacious in cancer therapy. Herein, recent advances in our understanding of ICLs and the biological responses they trigger are discussed.

nterstrand cross-links (ICLs) are lesions that covalently link two bases on the complementary strands of DNA. These lesions are formed by chemicals with two reactive electrophilic groups. The formation of ICLs is highly sequence-dependent because two nucleophilic groups on opposite strands must be aligned geometrically to enable the bifunctional cross-linking agent to react twice. A consequence of this complex chemistry is that cross-linking agents form not only ICLs but also monoadducts, DNA-protein cross-links, and intrastrand cross-

${ }^{3}$ Present address: Department of Metabolism and Aging, The Scripps Research Institute, Jupiter, Florida 33458. Editors: Errol C. Friedberg, Stephen J. Elledge, Alan R. Lehmann, Tomas Lindahl, and Marco Muzi-Falconi Additional Perspectives on DNA Repair, Mutagenesis, and Other Responses to DNA Damage available at www.cshperspectives.org Copyright (C) 2013 Cold Spring Harbor Laboratory Press; all rights reserved; doi: 10.1101/cshperspect.a012732 Cite this article as Cold Spring Harb Perspect Biol 2013;5:a012732 


\section{Clauson et al.}

links. This makes it challenging to study the biological impact of ICLs except via methods using site-specifically adducted synthetic duplex oligonucleotides.

ICLs prevent separation of the two DNA strands, which is a prerequisite for transcription and replication. Hence, ICLs act as an absolute block to essential cellular processes and are particularly detrimental to rapidly dividing cells. This has led to the extensive use of cross-linking agents as potent anticancer therapies. Remarkably, in contrast to these exogenous ICLs, the existence of endogenous ICLs has never been formally proven in mammalian tissues, likely because only a few ICLs can be tolerated by a cell. Indeed, it has been shown that 1-2 ICLs can be lethal to a repair-deficient yeast cell, whereas about 20-40 ICLs are lethal in repairdeficient mammalian cells (Magana-Schwencke et al. 1982; Phillips 1996). This has led to much speculation about the identity of the endogenous lesions that drove the evolution of wellconserved mechanisms of ICL repair.

Pathways of ICL repair are still not completely defined. Historically, mechanistic studies were largely driven by genetics owing to the availability of cell lines specifically sensitive to cross-linking agents and a strong link between defects in ICL repair and several genome instability disorders, most notably Fanconi anemia. ICL repair is presumed to occur via different mechanisms depending on the phase of the cell cycle (i.e., during DNA replication or outside of $S / G_{2}$ phase). In the past decade, there has been substantial progress on each of these fronts: identifying endogenous ICLs, developing methods to detect ICL lesions in complex biological samples, elucidating the mechanisms of ICL repair, and exploitation of cross-linking agents in the clinic. This article elaborates recent developments in the study of ICLs and their repair.

\section{ENDOGENOUS ICLs}

The best recognized cross-linking agents are all exogenous chemicals, such as the cancer chemotherapeutics nitrogen mustards, cisplatin, or mitomycin $\mathrm{C}$ and psoralen, which are used to treat skin disorders. Clearly, we did not evolve repair mechanisms for lesions induced by drugs developed in the last century. Recently, both synthetic and genetic approaches have been used to identify several sources of endogenous cross-linking agents. These agents arise from normal cellular metabolism and are summarized in Table 1. A number of aldehydes produced endogenously form ICLs in vitro (Stone et al. 2008; Guainazzi and Schärer 2010; Huang et al. 2010a; Garaycoechea et al. 2012). Endogenous production of aldehydes is strongly influenced by ingestion of dietary lipids and alcohol. This illustrates that endogenous DNA damage burdens can be altered through dietary changes. Abasic sites are extremely abundant endogenous lesions caused by spontaneous hydrolysis of the glycosidic bond in DNA. They exist in equilibrium between a ring-open aldehyde and ring-closed hemiacetal. The former is able to form ICLs by reacting with the exocyclic amino group of adenine or guanine residues on the opposite strand (Dutta et al. 2007; Guan and Greenberg 2009; Johnson et al. 2012b). These represent a potentially tremendously important class of endogenous ICLs because of the abundance of abasic sites. Nitric oxide, a signaling molecule important for vasoregulation that is produced as a by-product of nitrous acid, can cross-link guanine residues on the opposite strands (Kirchner et al. 1992; Guainazzi and Schärer 2010). Nitrous acid is a by-product of nitrates used in preservation of processed meats, again linking endogenous DNA damage burdens with diet.

\section{METHODS TO SYNTHESIZE, DETECT, AND QUANTITATE ICLs}

Synthesis of site-specific lesions in duplex DNA has been essential for defining the chemical and biological impact of specific DNA adducts. This approach is especially critical in the study of ICLs because all cross-linking agents, when used to create random damage in DNA, induce a myriad of lesions, of which ICLs are typically rare $(<10 \%)$. A major recent advance in the field has been the development of improved strategies to synthesize site-specific ICLs in duplex oligonucleotides (reviewed in Guainazzi 
DNA Interstrand Cross-Link Repair

Table 1. Endogenous sources of DNA interstrand cross-links

\begin{tabular}{|c|c|c|c|c|}
\hline ICL-inducing compounds & Target in DNA & Synthetic model & Endogenous sources & References \\
\hline $\begin{array}{l}\text { Aldehydes: Trans-4- } \\
\text { hydroxynonenal, } \\
\text { acetaldehyde, } \\
\text { malondialdehyde, } \\
\text { acrolein, } \\
\text { formaldehyde, } \\
\text { crotonaldehyde }\end{array}$ & $\begin{array}{l}5^{\prime} \text {-GC-non- } \\
\text { distorting; } \\
\text { 5'-CG- } \\
\text { distorting }\end{array}$ & $\begin{array}{l}\text { Stabilized } \\
\quad \text { trimethylene ICL } \\
\quad \text { between two } N^{2}-\mathrm{G}\end{array}$ & $\begin{array}{l}\text { Lipid peroxidation; } \\
\text { metabolism of } \\
\text { dietary } \\
\text { components } \\
\text { including coffee, } \\
\text { ripe fruit, and } \\
\text { alcohol }\end{array}$ & $\begin{array}{l}\text { Stone et al. 2008; } \\
\text { Huang et al. } \\
\text { 2010a; } \\
\text { Garaycoechea } \\
\text { et al. } 2012\end{array}$ \\
\hline Nitric oxide, nitrous acid & $\begin{array}{l}5^{\prime}-\mathrm{GC}< \\
5^{\prime}-\mathrm{CG}- \\
\text { distorting }\end{array}$ & $\begin{array}{l}\text { Nitrous acid-induced } \\
\text { ICL between two } \\
N^{2}-\mathrm{G}\end{array}$ & $\begin{array}{l}\text { Cell signaling; } \\
\text { acidification of } \\
\text { dietary nitrates }\end{array}$ & $\begin{array}{l}\text { Shapiro et al. } \\
\text { 1977; Harwood } \\
\text { et al. } 2000\end{array}$ \\
\hline $\begin{array}{l}\text { Oxidized abasic lesion: } \\
\text { 5'-(2-phosphoryl- } \\
\text { 1,4,dioxobutane) }\end{array}$ & $\begin{array}{l}\text { A on the } \\
\text { opposite } \\
\text { strand; } 3^{\prime} \text { to } \\
\text { the abasic site }\end{array}$ & $\begin{array}{l}\text { Photolabile precursor } \\
\text { built into an ss } \\
\text { oligonucleotide }\end{array}$ & Hypoxic conditions & $\begin{array}{l}\text { Guan and } \\
\text { Greenberg } \\
2009\end{array}$ \\
\hline $\begin{array}{l}\text { Ring-open aldehyde } \\
\text { form of an abasic } \\
\text { site } 3^{\prime} \text { to a } C \text { residue }\end{array}$ & G opposite the C & $\begin{array}{l}\text { AP site built into an ss } \\
\text { oligonucleotide; } \\
\text { ICL stabilized by } \\
\text { reduction with } \\
\mathrm{NaCNBH}_{3}\end{array}$ & $\begin{array}{l}\text { Spontaneous } \\
\text { hydrolysis of } \\
\text { purines or BER } \\
\text { repair } \\
\text { intermediates }\end{array}$ & $\begin{array}{l}\text { Dutta et al. 2007; } \\
\text { Johnson et al. } \\
\text { 2012a }\end{array}$ \\
\hline
\end{tabular}

ICL, interstrand cross link; ss, single strand; BER, base excision repair.

and Schärer 2010, and summarized in Tables 1 and 2). There are currently methods to synthesize site-specific ICLs arising from endogenous aldehydes or nitric oxide as well as common chemotherapeutic agents such as platinum drugs and nitrogen mustards (see Table 2). This has led to advances in our knowledge about the stability of ICLs and the amount of helical distortion these lesions introduce in DNA. This, in turn, may be important for determining whether these lesions are recognized by DNA repair machinery and are, therefore, repaired outside of $S / G_{2}$ phase of the cell cycle.

ICLs are challenging to detect and measure in biological samples. In addition to their relative rarity compared with other types of lesions, many ICLs are unstable and do not withstand isolation methods (Stone et al. 2008; Johnson et al. 2012b). Also, ICLs have a potent impact on cells that are replicating or transcribing their DNA. Hence, ICLs are not abundant in viable cells. Methods used to detect ICLs in cells or tissue samples include denaturing electrophoresis and, more recently, mass spectrometry and alkaline COMETassay. These methods and their strengths and weaknesses are elaborated in Table 3.
The creation of localized damage in subnuclear domains of cells is the in vivo equivalent of site-specific lesions. Local damage has been extremely useful for studying the recruitment of DNA repair proteins to sites of DNA damage (Volker et al. 2001). This enables identification of the sequential steps of repair mechanisms. The method depends on the use of a laser to induce a narrow path of DNA damage. 4,5' 8-trimethylpsoralen intercalates into DNA and can react with two nucleophilic groups upon photoactivation with UV-A. This was elegantly exploited for the study of ICL repair by creating psoralens conjugated with visible dyes or doxigenin (Thazhathveetil et al. 2007). Monolayers of cells are treated with conjugated psoralens followed by photoactivation with a UV-A laser, creating covalent DNA adducts, including ICLs, only in the path of the laser. Alternatively, a near infrared laser can be used for two photon activation of psoralen (Duquette et al. 2012).

Mass spectrometry (MS) is the most sensitive and specific method for detecting and quantifying DNA lesions. The only limitation is that, ideally, one should include an isotopi- 


\section{Clauson et al.}

Table 2. Common cross-linking agents and their target sequences

\begin{tabular}{|c|c|c|c|c|c|}
\hline $\begin{array}{l}\text { ICL-inducing } \\
\text { agent or group }\end{array}$ & $\begin{array}{c}\text { Target } \\
\text { sequence }\end{array}$ & Example agents $^{\mathrm{a}}$ & $\begin{array}{l}\text { Site-specific adduct } \\
\text { available for study? }\end{array}$ & $\begin{array}{l}\text { Cancers }^{\mathrm{a}} \\
\text { treated with } \\
\text { agents }\end{array}$ & References \\
\hline $\begin{array}{l}\text { Nitrogen } \\
\text { mustards }\end{array}$ & $5^{\prime}-\mathrm{GNC}$ & $\begin{array}{l}\text { Cyclophosphamide, } \\
\text { Melphalan, } \\
\text { Mechlorethamine, } \\
\text { Chlorambucil, } \\
\text { Ifosfamide, } \\
\text { Bendamustine }\end{array}$ & $\begin{array}{l}\text { Ring-opened } \\
\text { formamido- } \\
\text { pyrimidines with } \\
\text { improved } \\
\text { stability are used } \\
\text { to cross-link } \\
\text { dsDNA }\end{array}$ & $\begin{array}{l}\text { Lymphoma, } \\
\text { multiple } \\
\text { myeloma, } \\
\text { melanoma, } \\
\text { ovarian, } \\
\text { CLL, } \\
\text { NSCLC }\end{array}$ & $\begin{array}{l}\text { Ojwang et al. } \\
\text { 1989; Millard } \\
\text { et al. 1990; Rink } \\
\text { and Hopkins } \\
\text { 1995; } \\
\text { Guainazzi et al. } \\
2010\end{array}$ \\
\hline $\begin{array}{l}\text { Platinum } \\
\text { compounds }\end{array}$ & $5^{\prime}-\mathrm{GC}$ & $\begin{array}{l}\text { Cisplatin, } \\
\text { Carboplatin, } \\
\text { Oxaliplatin, } \\
\text { Satraplatin, } \\
\text { Picoplatin }\end{array}$ & $\begin{array}{l}\text { Cisplatin reacted } \\
\text { with an } \\
\text { oligonucleotide } \\
\text { containing a } \\
\text { unique guanine } \\
\text { can be annealed to } \\
\text { complementary } \\
\text { ssDNA }\end{array}$ & $\begin{array}{l}\text { Testicular, } \\
\text { ovarian, } \\
\text { NSCLC, } \\
\text { ovarian, } \\
\text { colorectal, } \\
\text { prostate, } \\
\text { breast }\end{array}$ & $\begin{array}{l}\text { Jamieson and } \\
\text { Lippard } 1999\end{array}$ \\
\hline Mitomycin C & $5^{\prime}-\mathrm{CG}$ & & $\begin{array}{l}\text { Efficient formation } \\
\text { of ICLs following } \\
\text { treatment of } \\
\text { duplex DNA with } \\
\text { MMC }\end{array}$ & $\begin{array}{c}\text { Esophageal, } \\
\text { bladder }\end{array}$ & Tomasz 1995 \\
\hline Psoralen & $5^{\prime}-\mathrm{TA}$ & $\begin{array}{l}\text { Furocoumarins from } \\
\text { plants and fungi }\end{array}$ & $\begin{array}{l}\text { Psoralen intercalates } \\
\text { into DNA and } \\
\text { requires UV-A } \\
\text { photoactivation } \\
\text { to covalently bind } \\
\text { DNA }\end{array}$ & $\begin{array}{l}\text { Cutaneous } \\
\text { T-cell } \\
\text { lymphoma }\end{array}$ & $\begin{array}{l}\text { Cimino et al. } \\
\text { 1985; } \\
\text { Thazhathveetil } \\
\text { et al. } 2007\end{array}$ \\
\hline $\begin{array}{l}\text { Chloro-ethyl } \\
\text { nitrosoureas }\end{array}$ & $\begin{array}{l}\text { G-C base } \\
\text { pair }\end{array}$ & Carmustine & $\begin{array}{l}\text { 3-(2-chloroethyl) } \\
\text { thymidine can be } \\
\text { synthesized in an } \\
\text { oligonucleotide } \\
\text { and annealed to } \\
\text { complementary } \\
\text { sequence }^{\text {b }}\end{array}$ & & $\begin{array}{l}\text { Fischhaber et al. } \\
\text { 1999; } \\
\text { Hentschel et al. } \\
2012\end{array}$ \\
\hline
\end{tabular}

CLL, chronic lymphocytic leukemia; NSCLC, nonsmall cell lung carcinoma.

${ }^{\mathrm{a}}$ The color coding indicates which tumor is treated with which drug.

${ }^{\mathrm{b}}$ Thymidine was more stable than adducts containing either guanine or cytosine.

cally labeled internal standard throughout sample processing to enable subtraction of artificial generation or loss of DNA damage. Thus, although MS has been applied to the measurement of chemotherapy-induced ICLs, it has not yet been applied to endogenous lesions because of their elusive identity and/or their chemical instability.

The COMET assay is frequently used to measure a variety of types of DNA lesions and
DNA repair intermediates. The method is unique in that it can be applied to single cells. Cell membranes are lysed and the nuclear DNA spread by electrophoresis under alkali conditions, creating a "comet tail" pattern of DNA. Longer tails represent more breaks in the chromosomal DNA, whereas shorter tails represent DNA that cannot be unraveled. This can be used to indirectly measure ICLs that prevent DNA unwinding. 
DNA Interstrand Cross-Link Repair

Table 3. Methods to detect and measure ICL lesions and their repair

\begin{tabular}{|c|c|c|c|c|}
\hline Method & End point measured & Advantages & Disadvantages & References \\
\hline $\begin{array}{l}\text { Local damage } \\
\text { with psoralen } \\
+ \text { UV-A }\end{array}$ & $\begin{array}{l}\text { Covalent addition of } \\
\text { psoralen to } \\
\text { chromatin in a } \\
\text { portion of a cell } \\
\text { nucleus }\end{array}$ & $\begin{array}{l}\text { Used to identify } \\
\text { proteins that co- } \\
\text { localize with ICLs to } \\
\text { determine the order } \\
\text { of events during ICL } \\
\text { repair }\end{array}$ & $\begin{array}{l}\text { Can only be used in } \\
\text { cells cultured in } \\
\text { monolayers; } \\
\text { cannot prove the } \\
\text { lesions are ICLs }\end{array}$ & $\begin{array}{l}\text { Thazhathveetil } \\
\text { et al. 2007; } \\
\text { Majumdar } \\
\text { et al. } 2008\end{array}$ \\
\hline $\begin{array}{l}\text { Mass } \\
\text { spectrometry }\end{array}$ & $\begin{array}{l}\text { Levels of mitomycin } \\
\text { C or other specific } \\
\text { ICL lesions in } \\
\text { genomic DNA }\end{array}$ & $\begin{array}{l}\text { Highly specific if using } \\
\text { tandem MS; highly } \\
\text { sensitive if using } \\
\text { isotopically labeled } \\
\text { internal standard; } \\
\text { applicable to cells, } \\
\text { tissues, or body fluids }\end{array}$ & $\begin{array}{l}\text { Limited to a single } \\
\text { lesion per } \\
\text { analysis and } \\
\text { those for which } \\
\text { synthetic } \\
\text { standards are } \\
\text { available }\end{array}$ & Paz et al. 2008 \\
\hline $\begin{array}{l}\text { Alkaline COMET } \\
\text { assay }\end{array}$ & $\begin{array}{l}\text { DNA damage that } \\
\text { restricts the } \\
\text { electrophoretic } \\
\text { mobility of DNA }\end{array}$ & $\begin{array}{l}\text { Single-cell } \\
\text { measurement of } \\
\text { DNA damage; } \\
\text { sensitive }\end{array}$ & $\begin{array}{l}\text { Subjective } \\
\text { quantification; } \\
\text { cannot be used } \\
\text { on lesions that are } \\
\text { unstable in alkali; } \\
\text { cannot be used } \\
\text { on tissues; } \\
\text { genome contains } \\
\text { multiple types of } \\
\text { DNA damage }\end{array}$ & $\begin{array}{l}\text { Olive et al. 1991; } \\
\text { Wu et al. 2009; } \\
\text { Spanswick et al. } \\
2010\end{array}$ \\
\hline
\end{tabular}

\section{GENES IMPLICATED IN ICL REPAIR}

A large number and diverse spectrum of genes are implicated the response to and repair of ICLs. These have largely been defined by deleting the gene and determining if the deletion renders cells sensitive to cross-linking agents (Table 4). Another way in which these genes have been identified is by defining new complementation groups of Fanconi anemia (FA). FA is a heterogeneous disease characterized by congenital anomalies, bone marrow failure, and high risk of acute myeloid leukemia (Auerbach 2009), currently consisting of 16 complementation groups. The FA proteins work coordinately to facilitate replication-dependent ICL repair (see below and Fig. 1). Intriguingly, virtually every protein that plays an enzymatic role in ICL repair also plays a role in at least one other DNA repair mechanism. This has made it extremely challenging to decipher the specific biological effect of ICL lesions (i.e., it is impossible to knock out ICL repair completely and uniquely). Conversely, defects in most of the other DNA repair/tolerance mechanisms (homologous recombination, nucleotide excision repair, mismatch repair, translesion synthesis, and base excision repair) render cells hypersensitive to cross-linking agents. This often cannot be completely ascribed to the fact that crosslinking agents generate a variety of lesions in addition to ICLs, and implicates proteins from each of these pathways in the repair of ICLs.

In general terms, ICL repair occurs through sequential excision of the lesion from one strand, then the other. This prevents the creation of multiple double-strand breaks (DSBs). During replication, the ICL is thought to be unhooked from the lagging strand template via two incisions $5^{\prime}$ and $3^{\prime}$ of the incision (Fig. 2 ). The $5^{\prime}$ cut creates a DSB, which must be repaired by $\mathrm{HR}$ to reestablish the replication fork. HR-mediated repair of this single DSB entails DNA end resection to create a $3^{\prime}$ overhang able to invade and capture sequence information from the lagging strand template. Before that can happen, a translesion polymerase 


\section{Clauson et al.}

Table 4. Genes associated with ICL sensitivity

\begin{tabular}{|c|c|c|c|}
\hline Gene name & Homologs & Function in ICL repair & $\begin{array}{l}\mathrm{ICL} \text { repair } \\
\text { mechanism }\end{array}$ \\
\hline FANCA & Mouse (Fanca) & Core complex member & $\begin{array}{l}\text { Replication } \\
\text { based }\end{array}$ \\
\hline FANCB & Mouse (Fancb) & Core complex member & $\begin{array}{l}\text { Replication } \\
\text { based }\end{array}$ \\
\hline FANCC & Mouse (Fancc) & Core complex member & $\begin{array}{l}\text { Replication } \\
\text { based }\end{array}$ \\
\hline FANCD1/BRCA2 & Mouse (Brca2) & Loading RAD51 onto DNA & $\begin{array}{l}\text { Replication } \\
\text { based }\end{array}$ \\
\hline FANCD2 & $\begin{array}{l}\text { Mouse (Fancd2); Drosophila } \\
\quad(\text { Fancd } 2) ; \text { C. elegans } \\
\quad(\text { fdc- } 2)\end{array}$ & $\begin{array}{l}\text { DNA binding; promotes DNA } \\
\text { damage signaling and repair } \\
\text { protein recruitment }\end{array}$ & $\begin{array}{l}\text { Replication } \\
\text { based }\end{array}$ \\
\hline FANCE & Mouse (Fance) & Core complex member & $\begin{array}{l}\text { Replication } \\
\text { based }\end{array}$ \\
\hline FANDF & Mouse (Fancf) & Core complex member & $\begin{array}{l}\text { Replication } \\
\text { based }\end{array}$ \\
\hline FANCG & Mouse (Fancg) & Core complex member & $\begin{array}{l}\text { Replication } \\
\text { based }\end{array}$ \\
\hline FANCI & $\begin{array}{l}\text { Mouse (Fanci); C. elegans } \\
\quad \text { (fnci-1); Drosophila } \\
\quad(\text { Fanci })\end{array}$ & $\begin{array}{l}\text { DNA binding; promotes DNA } \\
\text { damage signaling and repair } \\
\text { protein recruitment }\end{array}$ & $\begin{array}{l}\text { Replication } \\
\text { based }\end{array}$ \\
\hline $\begin{array}{l}\text { FANCJ/BRIP1/ } \\
\text { BACH1 }\end{array}$ & $\begin{array}{l}\text { Mouse (Brip1); C. elegans } \\
\quad(\text { dog- } 1)\end{array}$ & $\begin{array}{l}3^{\prime}-5^{\prime} \text { DNA helicase; preferred } \\
\text { substrate is branched DNA }\end{array}$ & $\begin{array}{l}\text { Replication } \\
\text { based }\end{array}$ \\
\hline FANCL & $\begin{array}{l}\text { Mouse (Fancl); Drosophila } \\
\quad(\text { Fancl) }\end{array}$ & $\begin{array}{l}\text { Ubiquitin ligase responsible for } \\
\text { monoubiquitination of } \\
\text { FANCD2-FANCI }\end{array}$ & $\begin{array}{l}\text { Replication } \\
\text { based }\end{array}$ \\
\hline FANCM & $\begin{array}{l}\text { Mouse (Fancm); Drosophila } \\
\text { (Cg7922); S. cerevisiae } \\
\text { (MPH1); S. pombe } \\
\text { (mfh1); Archae-Haloferax } \\
\text { volcanii }(\text { Hef })\end{array}$ & $\begin{array}{l}5^{\prime}-3^{\prime} \text { translocase; branch migration } \\
\text { activity; binds DNA in a } \\
\text { structure-specific manner and } \\
\text { recruits the core complex along } \\
\text { with BLM; involved in activation } \\
\text { of checkpoint }\end{array}$ & $\begin{array}{l}\text { Replication } \\
\text { based }\end{array}$ \\
\hline FANCN/PALB2 & Mouse (Palb2) & $\begin{array}{l}\text { Assists in BRCA2 localization to } \\
\text { DNA }\end{array}$ & $\begin{array}{l}\text { Replication } \\
\text { based }\end{array}$ \\
\hline FANCO/RAD51C & $\begin{array}{l}\text { Mouse (Rad51c); Arabidopsis } \\
\quad(\text { RAD51C); C. elegans (rad- } \\
\text { 51) ; Drosophila }(\text { Spn-D); } \\
\text { S. cerevisiae (DMC1); }\end{array}$ & $\begin{array}{l}\text { Involved in homologous } \\
\text { recombination }\end{array}$ & $\begin{array}{l}\text { Replication } \\
\text { based }\end{array}$ \\
\hline $\begin{array}{l}\text { FANCP/SLX4/ } \\
\quad \text { BTBD12 } \\
\text { SLX4 binds SLX1 }\end{array}$ & $\begin{array}{l}\text { Mouse (Slx4); Drosophila } \\
\quad \text { (Mus312) C elegans (slx4/ } \\
\text { him-18-slx1) S. cerevisiae } \\
\text { (SLX4); S. pombe (slx4- } \\
\text { eme1/mms4) }\end{array}$ & Scaffold protein for endonucleases & $\begin{array}{l}\text { Replication } \\
\text { based }\end{array}$ \\
\hline $\begin{array}{l}\text { FANCQ/ERCC4/XPF } \\
\text { XPF hetero- } \\
\text { dimerizes with } \\
\text { ERCC1 }\end{array}$ & $\begin{array}{l}\text { Mouse (Xpf-Ercc1); } \\
\text { Arabidopsis (?-ERCC1); } \\
\text { C. elegans (xpf-1 ercc-1); } \\
\text { Drosophila (Mei-9 Ercc1); } \\
\text { S. cerevisiae (RAD1- } \\
\text { RAD10); S. pombe (rad16- } \\
\text { swi10) }\end{array}$ & $\begin{array}{l}\text { Structure-specific endonuclease } \\
\text { with a preference for } 3^{\prime} \text { flaps }\end{array}$ & $\begin{array}{l}\text { Replication } \\
\text { based and } \\
\text { non- } \\
\text { replication } \\
\text { based }\end{array}$ \\
\hline
\end{tabular}


DNA Interstrand Cross-Link Repair

Table 4. Continued

\begin{tabular}{|c|c|c|c|}
\hline Gene name & Homologs & Function in ICL repair & $\begin{array}{l}\mathrm{ICL} \text { repair } \\
\text { mechanism }\end{array}$ \\
\hline $\begin{array}{l}\text { APITD1/MHF1 } \\
\quad \text { STRA13/MHF2 } \\
\text { C19orf40/FAAP24 }\end{array}$ & $\begin{array}{l}\text { Mouse (?, ?, Faap24); } \\
\text { S. cerevisiae (MHF1, } \\
\text { MHF2,?) }\end{array}$ & Accessory factors for FANCM & $\begin{array}{l}\text { Replication } \\
\text { based }\end{array}$ \\
\hline USP1/WDR48-UAF1 & C. elegans (uaf- 1$)$ & Deubiquitination of FANCD2 & $\begin{array}{l}\text { Replication } \\
\text { based }\end{array}$ \\
\hline FAN1 & $\begin{array}{l}\text { Mouse (Fan1); C. elegans } \\
\quad(\text { fan-1) }\end{array}$ & $\begin{array}{l}5^{\prime}-3^{\prime} \text { exonuclease, } 5^{\prime} \text {-flap } \\
\text { endonuclease. Binds to } \\
\text { monoubiquitinated FANCD2 }\end{array}$ & $\begin{array}{l}\text { Replication } \\
\text { based }\end{array}$ \\
\hline $\begin{array}{l}\text { MUS81-EME1 } \\
\text { MUS81 hetero- } \\
\text { dimerizes with } \\
\text { EME1 }\end{array}$ & $\begin{array}{l}\text { Mouse (Mus81-Eme1); } \\
\text { Arabidopsis (MUS81-?); } \\
\text { C. elegans (mus-81 } \\
\text { f56a6.4); Drosophila } \\
\text { (Mus81-Mms4); } \\
\text { S. cerevisiae (MUS81- } \\
\text { MMS4); S. pombe (mus81- } \\
\text { eme1) }\end{array}$ & $\begin{array}{l}\text { Structure-specific endonuclease } \\
\text { with a preference for } 3^{\prime} \text { flaps }\end{array}$ & $\begin{array}{l}\text { Replication } \\
\text { based }\end{array}$ \\
\hline SNM1A & $\begin{array}{l}\text { C. elegans ( } m r t-1) \text {; } \\
\text { S. cerevisiae (SNM1/PSO2) }\end{array}$ & $5^{\prime}$ exonuclease & $\begin{array}{l}\text { Replication } \\
\text { based }\end{array}$ \\
\hline SNM1B & S. cerevisiae (SNM1/PSO2) & $5^{\prime}$ exonuclease & $\begin{array}{l}\text { Replication } \\
\text { based }\end{array}$ \\
\hline$B R C A 1$ & $\begin{array}{l}\text { Mouse (Brca1); Arabidopsis } \\
\text { (BRCA1); C. elegans (brc- } \\
\text { 1); Drosophila (Muc14A); } \\
\text { S. cerevisiae (RAD18) }\end{array}$ & $\begin{array}{l}\text { Histone remodeling via ubiquitin } \\
\text { ligase activity targeting H2A } \\
\text { and CTIP }\end{array}$ & $\begin{array}{l}\text { Replication } \\
\text { based }\end{array}$ \\
\hline RAD51 & $\begin{array}{l}\text { Mouse (Rad51); Arabidopsis } \\
\quad(\text { RAD51); C. elegans (rad- } \\
\text { 51) ; Drosophila }(\text { Spn-A); } \\
\text { S. cerevisiae }(\text { RAD51); } \\
\text { S. pombe }(\text { rhp51); }\end{array}$ & $\begin{array}{l}\text { Homology search for template } \\
\text { DNA during homologous } \\
\text { recombination; promotes } \\
\text { strand exchange }\end{array}$ & $\begin{array}{l}\text { Replication } \\
\text { based }\end{array}$ \\
\hline $\begin{array}{l}\text { REV1 } \\
\text { DNA polymerase } \zeta \\
\text { DNA polymerase } v\end{array}$ & $\begin{array}{l}\text { Mouse (Rev1, Rev3l, Poln); } \\
\text { Arabidopsis (REV1, } \\
\text { ATREV3,?); C. elegans (rev- } \\
\text { 1, y37b11a.2,?); Drosophila } \\
\text { (Rev1, Mus205,?); } \\
\text { S. cerevisiae (REV1, } \\
\text { REV3,?); S. pombe (rev1, } \\
\text { rev3,?) }\end{array}$ & $\begin{array}{l}\text { Translesion polymerases required } \\
\text { for bypass of an ICL }\end{array}$ & $\begin{array}{l}\text { Replication } \\
\text { based and } \\
\text { non- } \\
\text { replication } \\
\text { based }\end{array}$ \\
\hline HELQ & Mouse (Helq) & Helicase required for ICL repair & $\begin{array}{l}\text { Replication } \\
\text { based }\end{array}$ \\
\hline$B L M$ & $\begin{array}{l}\text { Mouse }(\text { Blm }) \text {; C. elegans (him- } \\
\text { 6); Drosophila }(\text { Blm); } \\
\text { S. cerevisiae (SGS1); } \\
\text { S. pombe (rqh1) }\end{array}$ & $\begin{array}{l}\text { DNA helicase }\left(5^{\prime}-3^{\prime}\right) \text { important } \\
\text { for Holliday junction } \\
\text { dissolution and inhibition } \\
\text { of RAD51 strand invasion }\end{array}$ & $\begin{array}{l}\text { Replication } \\
\text { based }\end{array}$ \\
\hline RMI2 & $\begin{array}{l}\text { Mouse (Rmi2); S. cerevisiae } \\
\quad(\text { RMI2) }\end{array}$ & $\begin{array}{l}\text { Coordinates with BLM for Holliday } \\
\text { junction resolution }\end{array}$ & $\begin{array}{l}\text { Replication } \\
\text { based }\end{array}$ \\
\hline MRE11 & $\begin{array}{l}\text { Mouse (Mre11a); C. elegans } \\
\quad \text { (nrx-1); Drosophila } \\
\quad \text { (mre11); S. cerevisiae } \\
\quad \text { (MRE11); S. pombe }(\text { rad32) }\end{array}$ & $\begin{array}{l}\text { Component of the MRN complex } \\
\text { (MRE11-RAD50-NBS1), role in } \\
\text { homologous recombination }\end{array}$ & $\begin{array}{l}\text { Replication } \\
\text { based }\end{array}$ \\
\hline
\end{tabular}


C. Clauson et al.

Table 4. Continued

\begin{tabular}{|c|c|c|c|}
\hline Gene name & Homologs & Function in ICL repair & $\begin{array}{l}\mathrm{ICL} \text { repair } \\
\text { mechanism }\end{array}$ \\
\hline NBS1 & $\begin{array}{l}\text { Mouse }(\mathrm{Nbn}) ; \text { C. elegans } \\
\quad(x n p-1) ; \text { Drosophila }(\mathrm{Nbs}) \\
\text { S. cerevisiae }(\mathrm{XRS} 2) \\
\text { S. pombe }(n b s 1)\end{array}$ & $\begin{array}{l}\text { Component of the MRN complex } \\
\text { (MRE11-RAD50-NBS1), role in } \\
\text { homologous recombination }\end{array}$ & $\begin{array}{l}\text { Replication } \\
\text { based }\end{array}$ \\
\hline RAD50 & $\begin{array}{l}\text { Mouse }(\text { Rad50); C. elegans } \\
\quad(\text { rad-50); Drosophila } \\
\quad(\text { Rad50); S. cerevisiae } \\
\quad(\text { RAD50); S. pombe }(\text { rad50) }\end{array}$ & $\begin{array}{l}\text { Component of the MRN complex } \\
\text { (MRE11-RAD50-NBS1), role in } \\
\text { homologous recombination }\end{array}$ & $\begin{array}{l}\text { Replication } \\
\text { based }\end{array}$ \\
\hline ATR & $\begin{array}{l}\text { Mouse }(\text { Atr }) \text {; C. elegans (atl- } \\
\text { 1); Drosophila }(\text { Mei- } 41) ; \\
\text { S. cerevisiae }(M E C 1) \\
\text { S. pombe }(\text { rad } 3)\end{array}$ & $\begin{array}{l}\text { Kinase important for signaling } \\
\text { DNA damage to activate cell- } \\
\text { cycle checkpoints through } \\
\text { sensing of single-stranded DNA }\end{array}$ & $\begin{array}{l}\text { Replication } \\
\text { based }\end{array}$ \\
\hline CTIP/RBBP8 & $\begin{array}{l}\text { Mouse (Ctip); C. elegans } \\
\quad(\text { com- } 1) ; S . \text { cerevisiae } \\
\quad(\text { SAE } 2) ; S . \text { pombe }(\text { ctp } 1)\end{array}$ & $\begin{array}{l}\text { End resection during homologous } \\
\text { recombination }\end{array}$ & $\begin{array}{l}\text { Replication } \\
\text { based }\end{array}$ \\
\hline TOPIII $\alpha$ & $\begin{array}{l}\text { Mouse }(\text { TopIII } \alpha) \text { C. elegans } \\
\quad(\text { top-3) S. cerevisiae }(\text { TOP3) }\end{array}$ & $\begin{array}{l}\text { Topoisomerase involved in relaxing } \\
\text { supercoiled DNA during } \\
\text { homologous recombination }\end{array}$ & $\begin{array}{l}\text { Replication } \\
\text { based }\end{array}$ \\
\hline
\end{tabular}

Collis et al. 2006; Penkner et al. 2007; Youds et al. 2008; Meier et al. 2009; dos Santos and Van Houten 2010; Harris et al. 2010; Lestini et al. 2010; Yan et al. 2010a; Cherry et al. 2011; Deans and West 2011; McQuilton et al. 2012.

? Denotes no known homolog for one member of a complex.

${ }^{a}$ In C. elegans, there are two isoforms of rad-51 that are orthologous to S. cerevisiae, Rad51 and Dmc1.

must extend leading strand synthesis past the unhooked ICL to create a duplex molecule amenable to HR. Similarly, in nonreplicating cells, ICLs are thought to be repaired via unhooking from one strand, likely via nucleotide excision repair, followed by translesion synthesis (TLS) to fill the gap, then a second round of NER to completely remove the lesion. More details are provided in the following sections.

\section{FA Pathway}

Many of the genes that are important for protecting the genome from ICLs were discovered as encoding Fanconi anemia (FA) proteins. FA is a rare genetic disease characterized by congenital skeletal and renal anomalies, growth retardation, and bone marrow failure all of varying severity, and a high risk of acute myeloid leukemia. Diagnosis of FA is based on challenging the patient's cells with a cross-linking agent and measuring chromosome aberrations, in particular radial chromatid structures, indicative of faulty ICL repair. Currently, there are 16 FANC com- plementation groups: FANCA, FANCB, FANCC, FANCD1, FANCD2, FANCE, FANCF, FANCG, FANCI, FANCJ, FANCL, FANCM, FANCN, FANCO, FANCP, and FANCQ. Many of the proteins encoded by these genes are important for cell signaling in response to replication stress caused by DNA damage (Fig. 1). Other proteins are directly implicated in DNA repair. For example, FANCD1/BRCA2 is required for homologous recombination, whereas the most recently identified complementation group (FANCQ) encodes XPF, an endonuclease essential for nucleotide excision repair (NER) and ICL repair (Bogliolo et al. 2013; Kashiyama et al. 2013). The FA pathway plays an important role in DNA damage sensing and signaling during $S / G_{2}$ phase of the cell cycle in cells with ICLs (Fig. 1).

When a replication fork encounters an ICL, polymerization is arrested. This leads to the recruitment of FANCM to the stalled fork, where it binds unwound DNA. FANCM is a highly conserved member of the XPF-heterodimeric $3^{\prime}$-flap endonuclease family, but does not have nuclease activity as a result of changes in active 
DNA Interstrand Cross-Link Repair

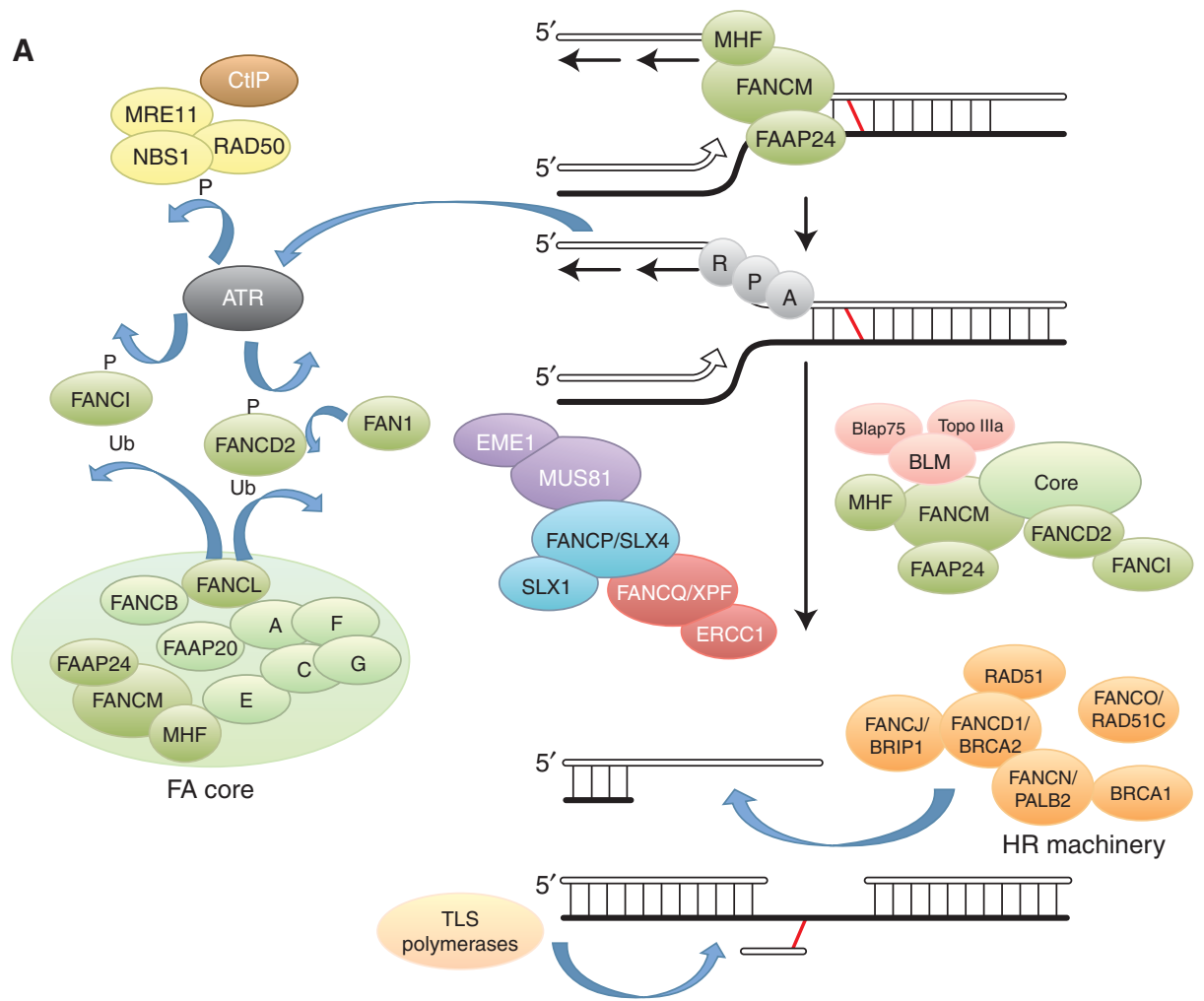

B

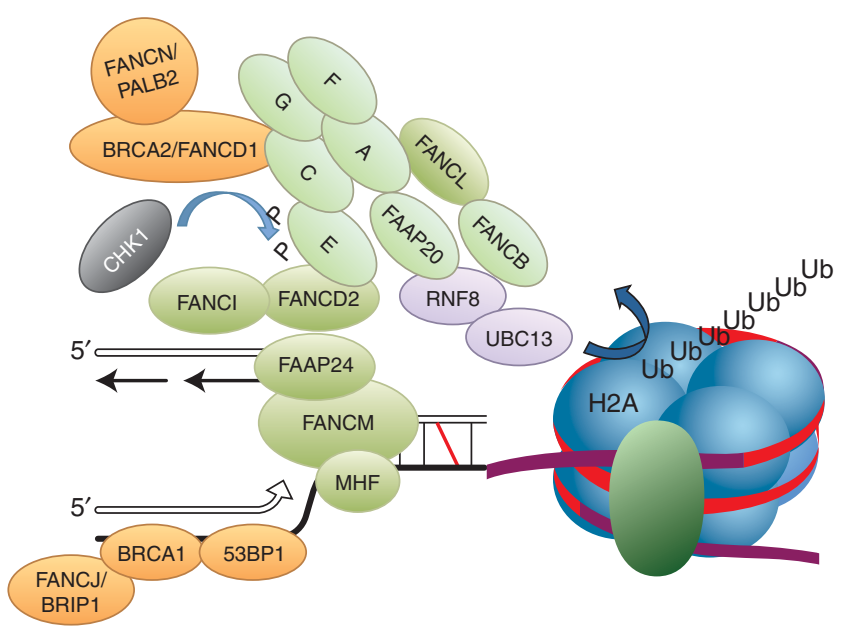

Figure 1. (A) Overview of the important steps in Fanconi anemia (FA) signaling pathway. Damage signaling begins with the recruitment of FANCM, FAAP24, and MHF to a stalled replication fork, binding to the unwound DNA. Remodeling of the fork by FANCM leads to recruitment of RPA, the ssDNA-binding protein. RPA localization to the DNA is required for ATR activation, which phosphorylates several targets, including the components of the MRN complex, FANCD2, and FANCI. The MRN complex associates with CtIP, which assists in DNA end resection during HR. The FA core complex assembles and includes FANCA, FANCB, FANCC, FANCE, FANCF, FANCG, FANCL, and FANCM, FAAP20, FAAP24, and MHF, using FANCM, FAAP24, and MHF to bind DNA. Assembly of the core complex stimulates FANCL to monoubiquitinate FANCD2 and FANCI. (Figure and legend continue on following page.) 
C. Clauson et al.
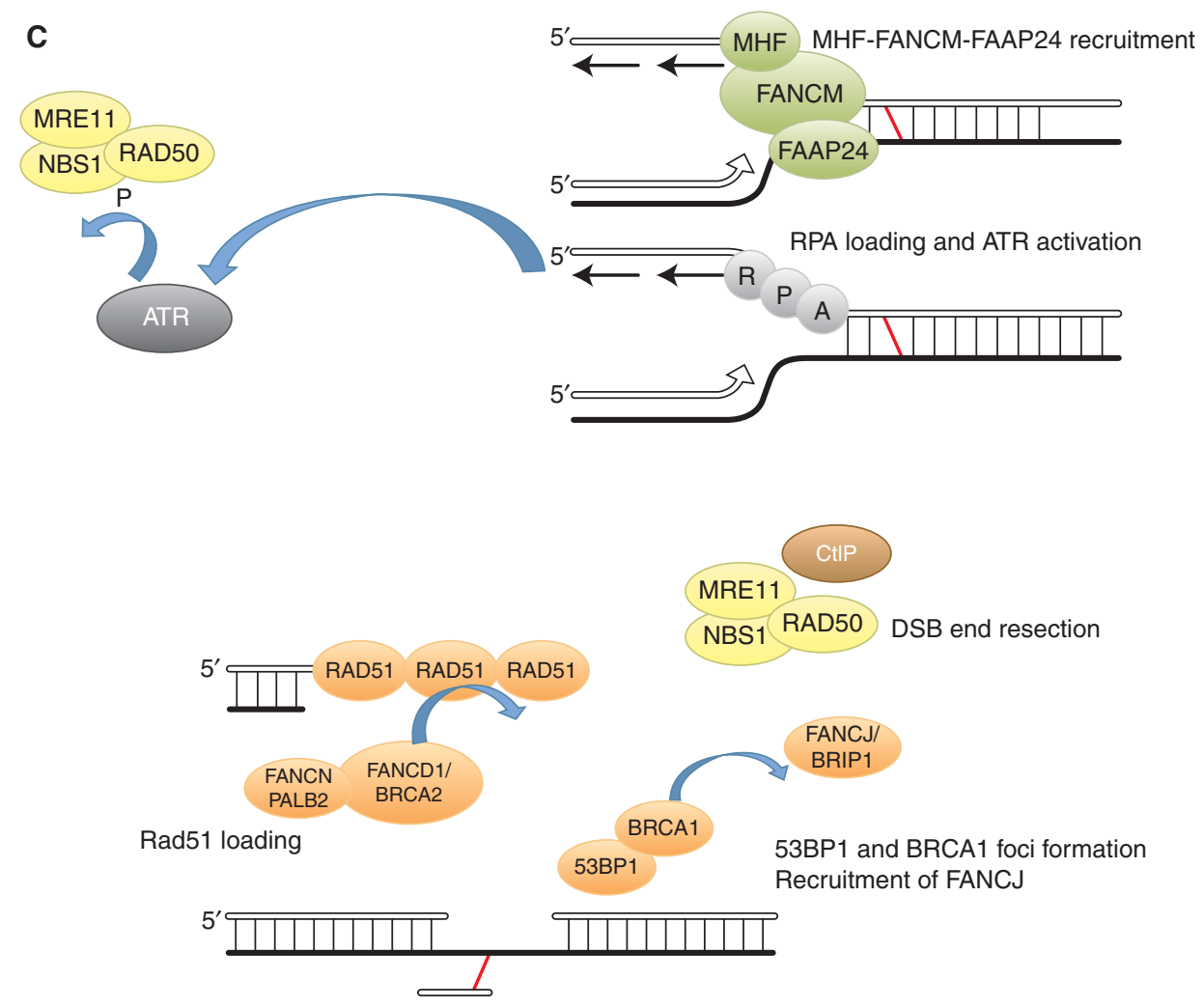

Figure 1. (Continued) Structure-specific endonucleases: MUS81-EME1 and ERCC1-XPF/FANCQ are recruited to the damage site via interaction with FANCP/SLX4. The core complex and FANCD2-FANCI are recruited to the chromatin where they facilitate resolution of the repair intermediate by TLS polymerases (REV1-Pol $\zeta$-Pol $\eta$ ) and the homologous recombination machinery, including FANCJ/BPIP1/BACH1, FANCD1/BRCA2, RAD51, FANCN/PALB2, FANCO/RAD51C, and BRCA1. (B) Details of the protein-protein interactions important for recruitment of FA proteins to sites of DNA damage. The core complex is recruited to chromatin via interaction of FAAP20 with RNF8 and the FANCC interaction with BRCA2/FANCD1. RNF8-UBC13 polyubiquitinates histone H2A, marking the site of ICL damage. FANCD2 and FANCI are recruited to chromatin via interaction between FANCD2 and FANCE of the core complex. FAAP20 also interacts with the TLS polymerase REV1. Dissolution of the complex is dependent on UAF1/USP1 deubiquitinating FANCD2 and FANCI. ( $C$ ) Events that occur independently of the FA core complex. Recruitment of FANCM, MHF, and FAAP24 to stalled forks does not require the core complex to be present or monoubiquitination of FANCD2 or FANCI. In addition, RPA loading and ATR activation do not require the core complex members. Finally, homologous recombination, in particular the formation of 53BP1 and BRCA1 foci, FANCJ recruitment to the chromatin, DSB end resection by MRN-CtIP, and RAD51 loading on the resected end, do not require the core complex.

site residues (Niedernhofer 2007). FANCM is recruited to chromatin with FAAP24 (another homolog of ERCC1, the heterodimeric partner of XPF), which assists FANCM binding to ssDNA (Ciccia et al. 2007), and a histone-fold protein complex called MHF, which stimulates replication fork remodeling (Yan et al. 2010b). Remodeling is accomplished by the ATP-depen- dent translocase activity of FANCM, which promotes migration of Holliday junctions and replication fork branch points (Gari et al. 2008a,b; Xue et al. 2008; Rosado et al. 2009). FANCM, FAAP24, and MHF are part of the FA core complex and are required for downstream events, including FANCD2 monoubiquitination (see below). Recent evidence suggests that the func- 
DNA Interstrand Cross-Link Repair

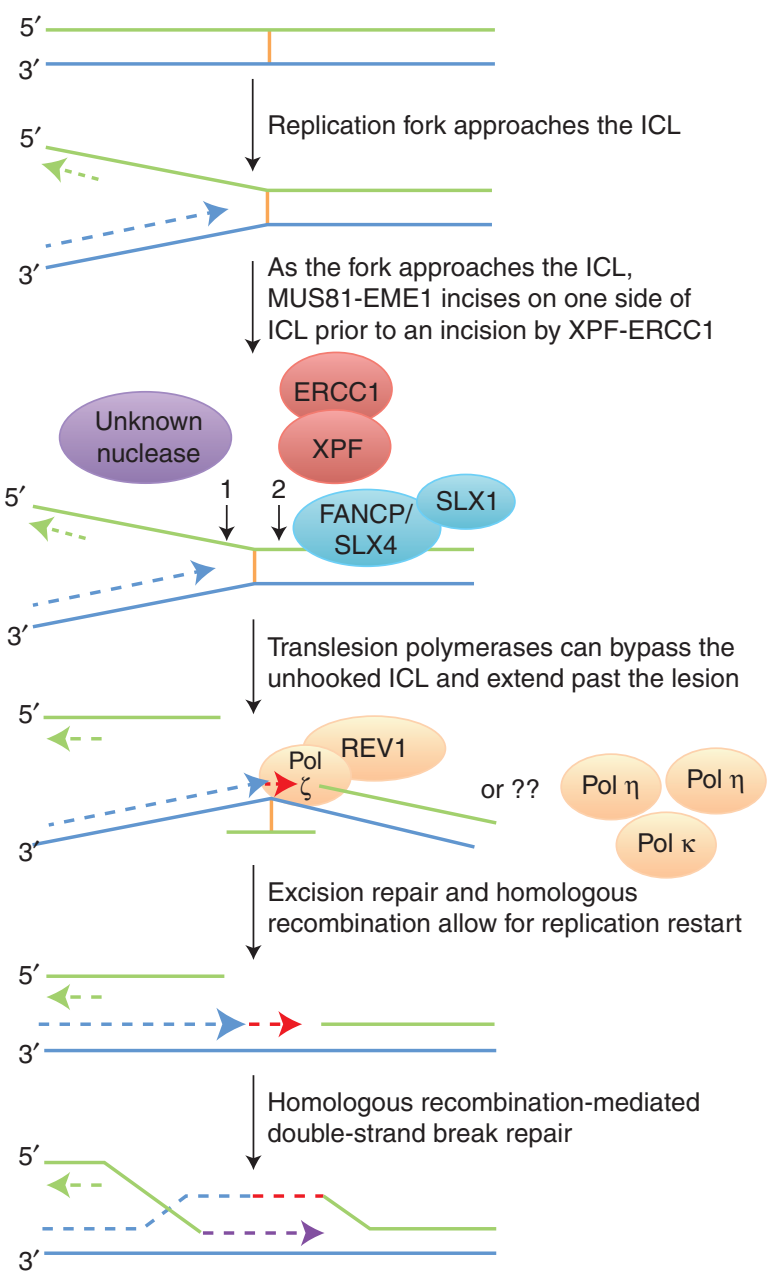

Figure 2. Current model for replication-dependent ICL repair. As a replication fork approaches an ICL, the fork stalls 20-40 nucleotides from the lesion. Two incisions are made on the lagging strand template. The first incision creates a single-ended double-strand break. The identity of the nuclease making this incision is currently not known. Then FANCQ/XPF-ERCC1 completely unhooks the ICL from the lagging strand template with a second nick. Both endonucleases are recruited to the damage site by FANCP/SLX4. Now translesion polymerases are able to bypass the unhooked ICL using the leading strand as a primer. Different TLS polymerases may be required to bypass various unhooked ICLs, whereas Pol $\zeta$-REV1 is adept at extending mismatches created by bypass insertion. This DNA synthesis is required to enable homologous recombination-mediated repair of the broken end.

tions of FANCM and FAAP24 are not fully epistatic in ICL repair (Wang et al. 2013).

FANCM-dependent translocation causes accumulation of RPA, the ssDNA-binding protein, at the ICL damage site (Huang et al. 2010b; Vare et al. 2012). RPA localization to chromatin is required for ATR activation and activation of the DNA damage checkpoint (Zou and Elledge
2003; Ben-Yehoyada et al. 2009). ATR, once activated, phosphorylates CHK1 in response to ICL damage (Cui et al. 2009), leading to activation of the kinase activity of CHK1 and blocking entry of the cell into mitosis. Checkpoint activation in response to ICLs during DNA replication requires the presence of the FA core complex (detailed below) but may also occur 


\section{Clauson et al.}

independently of replication (Ben-Yehoyada et al. 2009; Shen et al. 2009a).

ATR and its downstream kinases phosphorylate several FA proteins, amplifying damage signaling. FANCE is phosphorylated by CHK1 (Wang et al. 2007). FANCD2 and FANCI are phosphorylated by ATR (Andreassen et al. 2004; Smogorzewska et al. 2007). ATR also phosphorylates and activates the MRN complex (MRE11-RAD50-NBS1), which must resect the DSB created when the ICL is excised from the replication fork to generate long $3^{\prime}$ overhangs. These overhangs are necessary for the initiation of HR-mediated repair of the broken fork. The MRN complex interacts with CtIP, which is also required for DNA end resection (Sartori et al. 2007). Depletion of CtIP impairs recruitment of $\gamma \mathrm{H} 2 \mathrm{AX}, \mathrm{RPA}, \mathrm{ATR}$, and FANCD2 to local sites of ICL damage (Duquette et al. 2012), suggesting that end resection is an early event in ICL repair and critical for damage signaling.

The FA core complex includes FANCA, FANCB, FANCC, FANCE, FANCF, FANCG, FANCL, FANCM, FAAP20, FAAP24, and MHF. However, only FANCM, MHF, and FAAP24 have actually been shown to bind DNA (Fig. 1). Correct core complex assembly is necessary for proper downstream signaling, such as monoubiquitination of FANCD2 and FANCI, and HRmediated restoration of the replication fork. The majority of the core complex members function to stabilize the complex via important protein-protein interactions. For example, FANCE nuclear localization depends on its interaction with FANCC (Léveillé et al. 2006). In addition, FANCB and FANCL interact and the FANCLFANCA interaction is dependent on FANCB, FANCG, and FANCM, but not FANCC, FANCE, or FANCF (Kitao et al. 2006). In addition, FAAP20 is important for maintaining core complex stability, in particular through its interaction with FANCA and FANCD2 via the UBZ domain of FAAP20 (Yan et al. 2012). Some subunits of the core complex interact with other factors involved in ICL repair, for example, FAAP20 interacts with the translesion polymerase REV1 (Kim et al. 2012; Leung et al. 2012).

Once the FA core complex is assembled, phosphorylated FANCD2-FANCI is mono- ubiquitinated by the FANCL subunit of the core, which is an E3 ligase (Smogorzewska et al. 2007). Maintenance of the posttranslational modifications of FANCD2 and FANCI depends on both proteins being modified (Smogorzewska et al. 2007). Monoubiquitination of FANCD2 and FANCI is clearly a critical step in ICL repair as evidenced by the high conservation of these proteins (Collis et al. 2006; Deans and West 2009; Lee et al. 2010; Sugahara et al. 2012) and the fact that deubiquitination is required to complete ICL repair (Kim et al. 2009). FANCD2 monoubiquitination appears to be upstream of its chromatin translocation, as these events can be uncoupled (McCabe et al. 2008; Bhagwat et al. 2009). FANCD2 monoubiquitination does not depend on nucleolytic processing of the ICL (McCabe et al. 2008; Bhagwat et al. 2009) but is required for it (Knipscheer et al. 2009).

Recruitment of the FA core complex to chromatin is mediated by several protein-protein interactions (Fig. 1B). For example, recruitment of the core protein FAAP20 to chromatin requires polyubiquitination of histone $\mathrm{H} 2 \mathrm{~A}$ near the site of ICL damage, which is executed by RNF8-UBC13 (Yan et al. 2012). Recruitment of FANCD2 ${ }^{\mathrm{Ub}}$-FANCI ${ }^{\mathrm{Ub}}$ to the chromatin is dependent on the interaction of FANCD2 with core protein FANCE (Léveillé et al. 2006). Once FANCD2 translocates to the chromatin it promotes histone $\mathrm{H} 3$ mobility following crosslink damage, a process stimulated by FANCI, suggesting a role for FANCD2-FANCI in chromatin remodeling (Sato et al. 2012).

Several events in this signaling cascade and ICL repair appear to be independent of the FA core (Fig. 1C). These include recruitment of MHF-FANCM-FAAP24 to stalled forks, RPA loading, ATR activation, recruitment of 53BP1BRCA1, and subsequently FANCJ/BRIP1/ $\mathrm{BACH} 1$ to the chromatin, resection of the double-strand break (DSBs) created at the stalled fork by MRN-CtIP, RAD51 filament formation, and recruitment of FANCD1/BRCA2-FANCN/ PALB2 to the DSB. FANCJ interacts with MUTL homologs of the mismatch repair pathway, and it has been suggested that this interaction is critical for proper repair (Peng et al. 2007). Finally, USP1/UAF1 is the deubiquitinating enzyme 
responsible for removing the monoubiquitin from FANCD2 and FANCI to terminate the DNA damage signaling (Nijman et al. 2005; Cohn et al. 2007; Oestergaard et al. 2007). The entire process of FA signaling, checkpoint activation, and replication restart can take several hours to complete (Vare et al. 2012).

\section{Structure-Specific Nucleases}

Excision of DNA adducts typically requires two incisions on the same strand of DNA, $5^{\prime}$ and $3^{\prime}$ of the lesion. This is not sufficient to completely excise an ICL from DNA, but it is adequate to enable DNA synthesis past the lesion (Ho and Schärer 2010). Hence nucleases play a key role in ICL repair. There are multiple structure-specific nucleases that contribute to ICL repair, including XPF-ERCC1, MUS81-EME1, SLX4-SLX1, and three exo/endonucleases: FAN1, SNM1A, and SNM1B. At this point in time, it remains unclear precisely which nuclease is required for each of the multiple incisions and resections in ICL repair, and to what extent there is redundancy between the various enzymes.

XPF-ERCC1 is an endonuclease that nicks double-stranded DNA adjacent to a $3^{\prime}$ singlestrand region. It essential for NER of bulky monoadducts, but XPF and ERCC1 mutants are significantly more sensitive to cross-linking agents than other NER mutants, suggesting a role in ICL repair distinct from NER. Furthermore, mutating residues in ERCC1 that are critical for interaction with XPA severely compromises NER, but does not affect ICL repair, suggesting that ERCC1-XPF engages in distinct DNA repair pathways through specific proteinprotein interactions (Orelli et al. 2010). Recently, $X P F$ was identified as a complementation group of Fanconi anemia (FANCQ) (Bogliolo et al. 2013; Kashiyama et al. 2013). In the absence of XPF-ERCC1, ICL-induced replication-dependent DSBs accumulate (Niedernhofer et al. 2004; McCabe et al. 2008; Vare et al. 2012), indicating that at least one incision occurs at ICL sites in the absence of XPF-ERCC1. Furthermore, chromatin localization of FANCD2 is attenuated in the absence of XPF-ERCC1 (McCabe et al. 2008; Bhagwat et al. 2009), suggesting that nu- cleolytic processing of ICLs is necessary for the stable recruitment of FA proteins to repair foci. Cumulatively, studies to date indicate that XPFERCC1 is required to make one of the incisions near an ICL to unhook the ICL from one of the DNA strands. This is essential for enabling translesion synthesis past the ICL and ultimately HRmediated replication restart (Al-Minawi et al. 2009). Hence, as stated above, in the absence of this nuclease, DSBs accumulate in replicating cells treated with cross-linking agents. XPFERCC1 likely also plays a role in ICL repair outside $S / G_{2}$ phase of the cell cycle as part of the NER machinery (see below)

MUS81-EME1 is a highly conserved endonuclease (Table 4) related to XPF-ERCC1. In mammalian cells, deletion of MUS81 or EME1 causes hypersensitivity to cross-linking agents (Abraham et al. 2003; Hanada et al. 2006). The formation of DSBs in response to cross-linking agents is dependent on MUS81-EME1 (Hanada et al. 2006; Hanada et al. 2007; Wang et al. 2011). This suggests that these two endonucleases make incisions on different intermediates in ICL repair, with XPF-ERCC1 possibly acting in the primary sites of ICL repair, and MUS81-EME1 being active at stalled and/or regressed replication. Consistent with this notion, MUS81EME1 has a defined role in Holliday junction resolution (Chen et al. 2001), establishing complex DNA junctions as a favored substrate for this endonuclease. These studies strongly implicate MUS81-EME1 as important for converting replication forks stalled at ICLs to DSBs to initiate HR-mediated repair.

Another related endonuclease of critical importance to ICL repair is FANCP/SLX4-SLX1 (Kim et al. 2011; Stoepker et al. 2011). Slx4null $\left(b t b d 12^{-/-}\right)$mice mimic many of the key features of FA (Crossan et al. 2011). SLX4SLX1 is highly conserved, with homologs in yeast, worms (SLX4/HIM-18-SLX1), Drosophila (MUS312), and humans (BTBD12) (Andersen et al. 2009; Fekairi et al. 2009). Like MUS81-EME1, the endonuclease activity of SLX1 is important for Holliday junction resolution during $\mathrm{G}_{2}$ (Svendsen et al. 2009). SLX4 is likely to have SLX1-independent functions in ICL repair. Cells depleted of SLX4 are hypersen- 


\section{Clauson et al.}

sitive to cross-linking agents and have impaired HR (Muñoz et al. 2009). SLX4 contains a ubiquitin-binding zinc finger (UBZ) that interacts with monoubiquitinated FANCD2 and is required for recruitment of SLX4 to DNA-damage foci and suppression of cross-link sensitivity (Yamamoto et al. 2011). In addition to SLX1, SLX4 binds other nucleases, especially XPF, MUS81, and possibly SNM1B (Andersen et al. 2009; Fekairi et al. 2009; Salewsky et al. 2012). It is this scaffold function, recruiting other nucleases and targeting their activity to sites of ICL repair, which is believed to be the key function of SLX4 in ICL repair (Muñoz et al. 2009). Mutation analysis of SLX4 indicates that the interaction of SLX4 with XPF-ERCC1 is the only interaction that is absolutely essential for ICL repair (Kim et al. 2013).

FAN1 (Fanconi anemia-associated nuclease 1) is a structure-specific endonuclease and $5^{\prime}$ exonuclease (Kratz et al. 2010; Liu et al. 2010; MacKay et al. 2010; Smogorzewska et al. 2010). FAN1-depleted cells are hypersensitive to cross-linking agents and the protein associates with monoubiquitinated FANCD2 and FANCI through its UBZ domain (Huang and D’Andrea 2010; Liu et al. 2010), strongly suggesting a role in ICL repair. At which stage in ICL repair FAN1 acts is currently unknown, but it does not appear to be critical for an initial incision. FAN1 deficiency is not associated with FA, as patients with a microdeletion in $15 \mathrm{q} 13.3$ (which includes FAN1) have no detectable FAN1 protein yet, do not display any of the characteristic symptoms (Trujillo et al. 2012). Interestingly, patients with point mutations in FAN1 instead suffer from the chronic renal disease karyomegalic interstitial nephritis (Zhou et al. 2012).

Other nucleases implicated in ICL repair are hSNM1A and B, human homologs of the yeast Snm1/Pso2 protein, named for its identification in screens for mutants sensitive to nitrogen mustard and psoralen. Yeast SNM1/PSO2 mutants are hypersensitive to cross-linking agents but not UV-C or ionizing radiation, suggesting an exclusive role in ICL repair. Like FAN1, Snm1/ Pso2 has $5^{\prime}$-exonuclease and structure-specific endonuclease activity (Tiefenbach and Junop
2012). Mammalian cells have three Snm1/Pso2 homologs SNM1A, B, and C, with C being implicated in end-joining of DSBs (Cattell et al. 2010). SNM1A and SNM1B mutants are hypersensitive to cross-linking agents, and the double mutant is even more sensitive (Yan et al. 2010a), suggesting only partial redundancy in ICL repair. Both proteins have $5^{\prime}$ exonuclease activity; however, SNM1A is more active on high molecular weight DNA (Sengerová et al. 2012). Ectopic expression of hSNM1A suppresses the sensitivity of yeast pso2 mutants to cross-linking agents (Hazrati et al. 2008) showing functional conservation. Biochemical studies suggest that SNM1A might have a role in digesting a duplex around an ICL, thereby possibly generating an intermediate in ICL repair that can be processed more readily by TLS (Wang et al. 2011). Depletion of SNM1A leads to accumulation of ICLdependent replication-induced DBSs similar to what is observed in ERCC1-deficient cells. Indeed, SNM1A and ERCC1 are epistatic with respect to minor groove ICLs, suggesting that the two proteins act in a common pathway (Wang et al. 2011). SNM1B, in turn, is epistatic with FANCD2 and FANCI (Mason and Sekiguchi 2011) and coimmunoprecipitates with FANCP/SLX4 (Salewsky et al. 2012). These studies strongly implicate both nucleases in ICL repair but what their relative contributions are remains to be established.

\section{TLS Polymerases}

One of the major recent advances in our understanding of ICL repair has been the realization that TLS polymerases are essential for ICL repair in both $S / G_{2}$ and $G_{1}$ to bypass an ICL unhooked from one of the two cross-linked strands. This is vital to generate an intact template for HR-mediated repair of a replication-dependent DSB and excision of the ICL from the genome (see below). Consistent with this notion, a number of polymerases are capable of bypassing unhooked ICLs in vitro using model cross-linked DNA substrates. E. coli Pol IV (but not Pol II) can bypass unhooked $N^{2}-N^{2}$-guanine ICLs in a nonmutagenic manner (Kumari et al. 2008). A number of human TLS polymerases, including Pol $\eta$, 
Pol $\iota$, Pol $\kappa$, REV1, and Pol $v$, insert a base opposite and/or bypass structurally diverse ICLs. The efficiency of these polymerase-catalyzed reactions is dependent on the structure of the ICL and the amount of double-strand DNA surrounding the ICL. In general, ICLs embedded in fully duplex DNA are only very inefficiently bypassed by TLS polymerases, whereas those surrounded by only a short duplex $(2-5$ base pairs) are efficient substrates for polymerases (Minko et al. 2008a; Yamanaka et al. 2010; Ho et al. 2011; Klug et al. 2012).

A role of TLS polymerases in ICL repair is also strongly supported by genetics. In $S$. cerevisiae, mutations in genes encoding Pol $\zeta$ subunits Rev3 and Rev7 (McHugh et al. 2000; Sarkar et al. 2006) or REV1 (Larimer et al. 1989; Sarkar et al. 2006) render cells hypersensitive to cross-linking agents. Pol $\zeta$ is particularly important for cross-link resistance in nonreplicating cells in this organism (McHugh and Sarkar 2006). However, to date in vitro studies have been unable to show bypass of ICL damage by Pol $\zeta$ REV1 (Minko et al. 2008b; Ho et al. 2011), suggesting that other factors could be involved in lesion bypass. In contrast, Pol $\eta$ mutants (the only other TLS polymerase in yeast) are not sensitive to cross-linking agents (Grossmann et al. 2001; Wu et al. 2004; Sarkar et al. 2006).

In mammals, Pol $\zeta$ (consisting of the REV3 and REV7 subunits) and REV1 are key factors in ICL repair, as cells deficient in either one of these genes are exquisitely sensitive to cross-linking agents (Nojima et al. 2005; Gan et al. 2008). REV1 functions as a TLS polymerase scaffold and facilitates polymerase exchange (Sharma et al. 2013) and has additionally a deoxycytidyl transferase activity that may be involved in inserting a dCMP residue opposite an ICL (Minko et al. 2008b). Pol $\zeta$ is unique in its ability to extend from distorted primer-template termini, such as those formed by an insertion of a nucleotide at a lesion by another TLS polymerase.

One reason why mutations in or REV1 or $\mathrm{Pol} \zeta$ render cells hypersensitive to cisplatin or $\mathrm{MMC}$ is that these two enzymes are involved in replication-dependent and -independent ICL repair pathways. The sensitivity to cross-linking agents caused by mutations in the REV3 sub- unit of Pol $\zeta$ is epistatic to mutations in the Fanconi anemia pathway in chicken DT40 cells (Sonoda et al. 2003; Niedzwiedz et al. 2004; Nojima et al. 2005), suggesting that it is a result of defect in replication-dependent ICL repair. A role of Pol $\zeta$ and Rev1 in replication-dependent ICL repair is also strongly supported by studies in Xenopus egg extracts (see below) (Räschle et al. 2008). In vertebrates, REV1 and Pol $\zeta$ are also required for bypass of a psoralen, MMC or cisplatin site-specific ICL in a nonreplicating plasmid-based reporter assay (Shen et al. 2006; Enoiu et al. 2012).

The importance of other TLS polymerases for ICL repair is less clear-cut. Human cells deficient in Pol $\eta$ (XP-V patient cells) are hypersensitive to cross-linking agents such as cisplatin or psoralen (Misra and Vos 1993; Raha et al. 1996; Albertella et al. 2005; Chen et al. 2006; Mogi et al. 2008). Human Pol $\eta$ can bypass various structurally distinct unhooked ICLs (Ho et al. 2011). Pol $\eta$ was shown to be involved, but not essential in the repair of plasmid-borne MMC and psoralen ICLs in replication-independent ICL repair (Wang et al. 2001; Zheng et al. 2003). These studies suggest that Pol $\eta$ has a role in the repair of certain ICLs, but that this role may be at least partially redundant.

Pol $\kappa$-deficient cells are hypersensitive to cross-linking agents, in particular the minor groove ICL forming agent MMC, suggesting a role of Pol $\kappa$ in bypassing minor groove lesions (Minko et al. 2008a; Williams et al. 2012). Consistent with this observation, Pol $\kappa$ can bypass $N^{2}-N^{2}$ guanine ICLs model substrates efficiently (Minko et al.2008b), whereas reduced activity is observed using cisplatin and nitrogen mustard substrates, which are major groove ICLs (Ho et al. 2011). Pol $\kappa$ is therefore likely to have an important role in the repair of a subset of ICL lesions.

Pol $v$-knockdown cells are hypersensitive to MMC (Zietlow et al. 2009; Moldovan et al. 2010). Pol $v$ interacts with FANCD2-FANCI as well as RAD51, suggesting a role in replicationdependent ICL repair (Moldovan et al. 2010). In vitro, Pol $v$ efficiently bypasses major groove ICLs and, with very low efficiency, psoralen ICLs (Zietlow et al. 2009; Yamanaka et al. 


\section{Clauson et al.}

2010). The context in which Polv might operate in ICL repair remains to be determined.

In summary, our current understanding of TLS polymerases is that REV 1 and Pol $\zeta$ have essential roles in ICL repair and that other enzymes have minor roles and may contribute to the repair of ICLs with particular structures or in specific pathways or situations.

\section{Homologous Recombination}

The importance of HR in the repair of ICLs was established some time ago in lower organisms (E. coli, S. cerevisiae) (Sinden and Cole 1978a,b; Jachymczyk et al. 1981). More recently, several key mammalian HR proteins were identified as part of the FA pathway, including FANCD1/BRCA2, FANCN/PALB2, FANCJ/ BRIP1/BACH1, and FANCO/RAD51C. Accordingly, depletion of key proteins required for HR in human fibroblasts causes hypersensitivity to cross-linking agents and the formation of radial structures when exposed to mitomycin C (Hanlon Newell et al. 2008), a diagnostic criterion of FA. Interestingly, the same is true if key proteins required for nonhomologous end-joining of DSBs are depleted (Hanlon Newell et al. 2008).

Once FANCM-FAAP24-MHF unwinds DNA behind a stalled replication fork, ssDNA is exposed, RPA is bound, ATR is activated followed by FA pathway activation, and the HR machinery is recruited to the stalled fork. CtIP coordinates the recognition and resection of DSBs by MRE11-RAD50-NBS1 to create a $3^{\prime}$ singlestrand overhang amenable to HR (Sartori et al. 2007) and is required for resistance to cross-link damage (Duquette et al. 2012). CtIP is ubiquitinated by BRCA1 and has been shown to accumulate at sites of locally induced ICLs downstream from FANCM (Duquette et al. 2012). It then promotes accumulation of RPA, ATR, and FANCD2 at damage sites.

BRCA2/FANCD1 loads RAD51 onto stalled forks and this process is independent of FA proteins (Kitao et al. 2006; Long et al. 2011). Studies in Xenopus reveal that RAD51 is loaded onto single-stranded regions of the stalled fork even before nucleolytic incisions occur (Long et al. 2011). MCM8 and MCM9 are two replicative helicase-related $\mathrm{Mcm}$ family members that form a complex that is required for resistance to cross-linking agents (Nishimura et al. 2012). The proteins form nuclear foci that colocalize with RAD51 after cross-link damage and are required for HR repair of ICL-induced replication-dependent DSBs.

Once incisions are made, the RAD51 nucleofilament promotes strand invasion of the broken end into the intact sister chromatid for HR-mediated repair of the DSB. RAD51 colocalizes with FANCD2 after cross-link damage; however, recruitment of either protein to the chromatin does not depend on the presence of the other (Kitao et al. 2006). RAD51C, encoding a RAD51 paralog, was identified as a Fanconi anemia complementation group (FANCO) (Vaz et al. 2010). FANCO/RAD51C also functions downstream of FANCD2 monoubiquitination and DSB formation, but is essential for HR-mediated repair of ICL-induced replication-dependent DSBs (Somyajit et al. 2012). Additional RAD51 paralogs, in particular XRCC2 and XRCC3, also contribute to the HR step in ICL repair (Liu et al. 1998).

FANCD1/BRCA2 is a single-strand DNAbinding protein that promotes RAD51-dependent strand invasion. FANCN/PALB2 binds BRCA2 to promote strand invasion. FANCJ/ $\mathrm{BACH} 1 / \mathrm{BRIP} 1$ is a $5^{\prime}$ to $3^{\prime}$ helicase that binds BRCA1. All three of these FA proteins are enriched in the chromatin fraction of cells after cross-link damage during the $S / G_{2}$ phase of the cell cycle and chromatin recruitment is independent of the FA core complex (Shen et al. 2009b). BRCA1 also plays a role in DNA damage signaling and nonhomologous end-joining of DSBs. Hence, BRCA1 may facilitate ICL repair through other mechanisms that are independent of HR (Bunting et al. 2012). Restoration of replication forks stalled by ICLs is a slow process requiring several hours (Vare et al. 2012).

\section{MODEL FOR REPLICATION-DEPENDENT ICL REPAIR}

Although the cell biology and genetic studies discussed above have provided a list of players 
involved in ICL repair, they have not provided a mechanistic basis for the individual steps. In $\mathrm{S}$ phase, ICL repair is triggered by the complete blockage of the advancement of the replication fork at an ICL. As a consequence, ICLs show their greatest toxicity during $S$ phase making their repair at that stage critical. Biochemical studies of replication-dependent ICL repair have been challenging, but the use of a biochemical system using plasmids with site-specific ICLs and a defined replication system in Xenopus egg extract have provided a basis for a biochemical model (Räschle et al. 2008; Knipscheer et al. 2009; Long et al. 2011) of replication-dependent ICL repair (Fig. 2).

As the leading strand of a replication fork approaches the ICL, it stalls approximately $20-$ 40 nucleotides from the ICL, consistent with a blockage of the replicative helicase, the MCM complex. The $5^{\prime}$ ends of the lagging strands also stalls at variable distances from the lesion. This is believed to lead to the disassembly of the replicative helicase and enabling further approach of the replication fork toward the ICL. In the Xenopus system and possibly in human cells, two replication forks may converge at the ICL. The basic steps discussed below are likely to be similar whether triggered by one or two replication forks. This close encounter of the replication fork with the ICLs coincides with the activation of the FA pathway as evidenced the ubiquitination of FANCD2/FANCI complex. FA pathway activation is required for further steps in ICL repair in the Xenopus system (Knipscheer et al. 2009).

The first step is likely the unhooking of the ICL from the lagging strand template by two incisions on either side of the ICL. This unhooking step is thought to be mediated by two different structure-specific endonucleases with opposite polarities. Although the identity of these enzymes remains to be shown, it is likely that XPF-ERCC1 makes the incision $3^{\prime}$ to the ICL on the lagging strand template (Fig. 2). The rationale for this is that ICLs are converted to DSBs in the absence of XPF-ERCC1, suggesting the $5^{\prime}$ cut still occurs. In the absence of MUS81-EME1, ICLs are not converted to DSBs, which could be interpreted as a role in unhooking ICLs. However MUS81-EME1 has the same polarity as XPF-ERCC1, which is incompatible for making the $5^{\prime}$ incision on the lagging strand template. Current thinking is that MUS81-EME1 incises stalled or regressed replication forks in a different context, such as converging forks or persistent DNA damage (Wang et al. 2011). Hence, the identity of the nuclease making the incision $5^{\prime}$ to the ICL on the lagging strand template remains unclear. FAN1 has the correct polarity but is likely to act at a later step in ICL repair. SLX1 is another candidate, but it is currently unclear how important its role in ICL repair is, because mutating the SLX1-binding site of scaffold protein SLX4 does not render cells hypersensitive to cross-linking agents. Another possibility is that a single incision by XPF-ERCC1 could be followed by an exonucleolytic degradation of the lagging strand around the ICL by SNM1A (Wang et al. 2011).

These incision reactions lead to the formation of a DSB in the lagging strand and an unhooked ICL in the leading strand. The unhooked ICL then provides a template for translesion synthesis. This step likely requires multiple TLS polymerases for DNA synthesis up to the lesion, bypassing the lesion and extending from a potentially mismatched primer template. Based on genetics and depletion studies in the Xenopus system, REV1 and Pol $\zeta$ are the likely key players in this step, although the identity of the TLS polymerase inserting a dNTP opposite the ICLs and extending past the incision step may be dependent on the structure of the ICL (Minko et al. 2008a; Räschle et al. 2008). After translesion synthesis, the leading strand will be extended (likely by Pol $\zeta$ ) and ligated to the first downstream Okazaki fragment (Räschle et al. 2008). This yields an intact sister chromatid that can serve as a target for initiation of HR-mediated DSB repair.

Strand invasion by the $3^{\prime}$ overhang of the lagging strand template occurs to capture sequence lost at the DSB created during the unhooking of the ICL. RAD51 was shown to have the expected key role in this step using the Xenopus system (Long et al. 2011). Interest- 


\section{Clauson et al.}

ingly, RAD51 appears to interact with ICLcontaining sites before activation of FANCD2FANCI, pointing to a tight coordination of all the steps involved. Completion of the recombination step and resolution of HR intermediates is dependent on FANCD2-FANCI. How other FA and HR proteins contribute to the regeneration of an intact replication fork remains to be determined. This process formally generates a fully replicated DNA molecule that still contains an unhooked ICL. This unhooked ICL does not present an obstacle for the completion of S phase and may eventually be removed by NER.

\section{MODEL FOR REPLICATION-INDEPENDENT ICL REPAIR PATHWAY}

There is also strong evidence that ICLs are repaired in the absence of DNA replication. Such repair events were initially observed using sitespecifically cross-linked reporter plasmids that have no replication origins necessary to allow replication-dependent repair to occur (Wang et al. 2001; Zheng et al. 2003; Shen et al. 2006; Hlavin et al. 2010; Enoiu et al. 2012). Psoralen, MMC, cisplatin, and alkyl ICLs are repaired in this context, which depends on NER proteins and TLS polymerases, in particular REV1 and Pol $\zeta$. Whereas most ICLs are recognized by both global genome NER and transcriptioncoupled NER, the removal of cisplatin ICL was absolutely dependent on the transcriptioncoupled NER protein CSB (Enoiu et al. 2012). Based on these observations, it has been suggested that this repair pathway involves two rounds of unhooking the ICL from one strand plus gap-filling DNA synthesis (Fig. 3).

Biochemical studies aimed at determining how the NER machinery and possibly other proteins recognize and incise ICLs have not yet yielded many insights. Also, because in NER the two DNA strands are unwound around the lesion, it is not obvious that NER proteins would be able to make an incision on both sides of an ICL. Indeed, in in vitro studies with model ICL substrates and cell-free extracts, NER proteins did not incise cisplatin ICLs (Zamble et al.
1996), whereas with psoralen or alkyl ICL substrates dual incisions are observed only on one side ( $5^{\prime}$ to the ICL) (Bessho et al. 1997; Mu et al. 2000; Smeaton et al. 2008). Whether such intermediates are further processed by exonucleases to facilitate removal, or if additional factors are required to facilitate dual incisions around ICLs, remains to be determined. Interestingly, certain ICLs are incised in an NER-independent manner, but the factors responsible for this alternative incision remain to be identified (Smeaton et al. 2008). It is further possible that additional proteins, for example the mismatch repair complex MutS $\beta$, could bind ICLs and modulate or facilitate repair processes (Zhao et al. 2009).

Involvement of NER proteins in replicationindependent ICL repair is further supported by studies using locally induced psoralen damage, which clearly showed that the psoralen lesions are repaired in $G_{1}$ cells and that the NER proteins XPC, XPB, XPA, and XPF are recruited to damaged sites (Muniandy et al. 2009). Genetic studies revealed that simultaneous depletion of CSB and FANCD2 causes additive sensitivity to cross-linking agents, suggesting that replication-independent ICL repair is critical for reducing the cellular burden of cross-link damage (Enoiu et al. 2012). Similar repair pathways have been described in S. cerevisiae and E. coli, suggesting that it is evolutionarily conserved (Berardini et al. 1997, 1999; Sarkar et al. 2006).

In summary, there has been an explosion of new information about ICL damage and repair in the last decade. This includes the identification of endogenous lesions and new repair factors. Challenges for the future include detecting and quantifying endogenous ICLs and precisely defining the sequential steps of ICL repair. This likely will require further advances in the analytical tools used to measure both DNA damage and repair. ICL damage is implicated in causing cancer and driving organism aging. ICL repair is implicated in genetic predispositions to cancer as well as resistance to cancer therapy. Hence, continued advances in this field are anticipated to have a significant impact on predicting cancer risk and therapeutic outcomes as well as identifying behavior aspects (diet, 
DNA Interstrand Cross-Link Repair

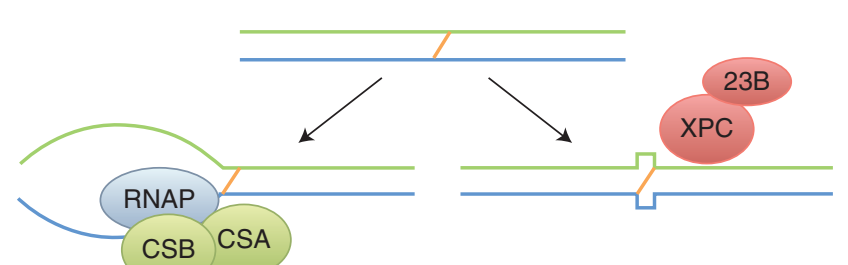

Helix distortion causing
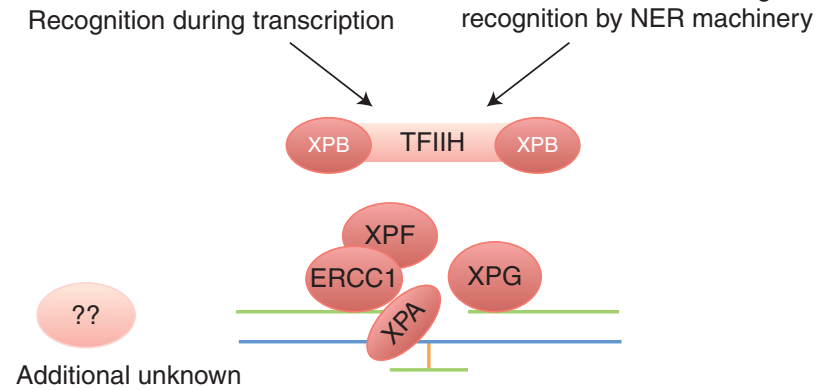
factors may be involved

Recruitment of NER factors, incision around the ICL

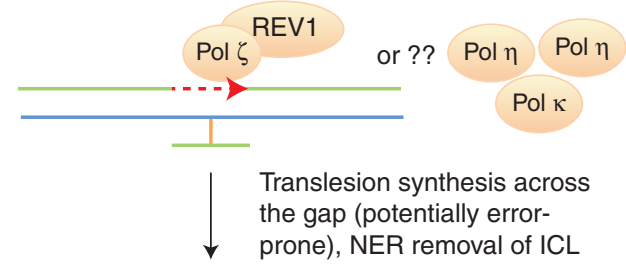

Figure 3. Current model for replication-independent ICL repair. If an ICL occurs in nonreplicating cells, it may be recognized by interfering with transcription or because it induces helix distortion, which is recognized by the nucleotide excision repair pathway. This could trigger recruitment of downstream NER factors including XPFERCC1. Incisions around the lesion on one strand of DNA unhook the lesion from that strand. Translesion polymerases can bypass the ICL and fill the gap with new DNA synthesis. This is sufficient to restore doublestrand DNA that is free of interstrand cross-links.

exposures, drugs) that promote cancer and aging.

\section{REFERENCES}

Abraham J, Lemmers B, Hande MP, Moynahan ME, Chahwan C, Ciccia A, Essers J, Hanada K, Chahwan R, Khaw AK, et al. 2003. Emel is involved in DNA damage processing and maintenance of genomic stability in mammalian cells. EMBO J 22: 6137-6147.

Albertella MR, Green CM, Lehmann AR, O'Connor MJ. 2005. A role for polymerase $\eta$ in the cellular tolerance to cisplatin-induced damage. Cancer Res 65: 9799-9806.

Al-Minawi AZ, Lee Y-F, Håkansson D, Johansson F, Lundin C, Saleh-Gohari N, Schultz N, Jenssen D, Bryant HE, Meuth M, et al. 2009. The ERCC1/XPF endonuclease is required for completion of homologous recombination at DNA replication forks stalled by inter-strand crosslinks. Nucleic Acids Res 37: 6400-6413.

Andersen SL, Bergstralh DT, Kohl KP, LaRocque JR, Moore CB, Sekelsky J. 2009. Drosophila MUS312 and the vertebrate ortholog BTBD12 interact with DNA structure-specific endonucleases in DNA repair and recombination. Mol Cell 35: 128-135.

Andreassen PR, D'Andrea AD, Taniguchi T. 2004. ATR couples FANCD2 monoubiquitination to the DNA-damage response. Genes Dev 18: 1958-1963.

Auerbach AD. 2009. Fanconi anemia and its diagnosis. $\mathrm{Mu}$ tat Res 668: 4-10.

Ben-Yehoyada M, Wang LC, Kozekov ID, Rizzo CJ, Gottesman ME, Gautier J. 2009. Checkpoint signaling from a single DNA interstrand crosslink. Mol Cell 35: 704715 . 


\section{Clauson et al.}

Berardini M, Mackay W, Loechler EL. 1997. Evidence for a recombination-independent pathway for the repair of DNA interstrand cross-links based on a site-specific study with nitrogen mustard. Biochemistry 36: 35063513.

Berardini M, Foster PL, Loechler EL. 1999. DNA polymerase II $(p o l B)$ is involved in a new DNA repair pathway for DNA interstrand cross-links in Escherichia coli. J Bacteriol 181: $2878-2882$.

Bessho T, Mu D, Sancar A. 1997. Initiation of DNA interstrand cross-link repair in humans: The nucleotide excision repair system makes dual incisions $5^{\prime}$ to the crosslinked base and removes a 22- to 28-nucleotide-long damage-free strand. Mol Cell Biol 17: 6822-6830.

Bhagwat N, Olsen AL, Wang AT, Hanada K, Stuckert P, Kanaar R, D'Andrea A, Niedernhofer LJ, McHugh PJ. 2009. XPF-ERCC1 participates in the Fanconi anemia pathway of cross-link repair. Mol Cell Biol 29: 6427-6437.

Bogliolo M, Schuster B, Stoepker C, Derkunt B, Su Y, Raams A, Trujillo JP, Minguillon J, Ramirez MJ, Pujol R, et al. 2013. Mutations in ERCC4, encoding the DNA-repair endonuclease XPF, cause Fanconi anemia. Am J Human Genet 92: 800-806.

Bunting SF, Callen E, Kozak ML, Kim JM, Wong N, LopezContreras AJ, Ludwig T, Baer R, Faryabi RB, Malhowski A, et al. 2012. BRCA1 functions independently of homologous recombination in DNA interstrand crosslink repair. Mol Cell 46: 125-135.

Cattell E, Sengerová B, McHugh PJ. 2010. The SNM1/Pso2 family of ICL repair nucleases: From yeast to man. Environ Mol Mutagen 51: 635-645.

Chen X-B, Melchionna R, Denis C-M, Gaillard P-HL, Blasina A, Van de Weyer I, Boddy MN, Russell P, Vialard J, McGowan CH. 2001. Human Mus81-associated endonuclease cleaves Holliday junctions in vitro. Mol Cell 8: 1117-1127.

Chen Y-w, Cleaver JE, Hanaoka F, Chang C-f, Chou K-m. 2006. A novel role of DNA polymerase $\eta$ in modulating cellular sensitivity to chemotherapeutic agents. Mol Cancer Res 4: 257-265.

Cherry JM, Hong EL, Amundsen C, Balakrishnan R, Binkley G, Chan ET, Christie KR, Costanzo MC, Dwight SS, Engel SR, et al. 2011. Saccharomyces Genome Database: The genomics resource of budding yeast. Nucleic Acids Res 40: D169-D179.

Ciccia A, Ling C, Coulthard R, Yan Z, Xue Y, Meetei AR, Laghmani EH, Joenje H, McDonald N, de Winter JP, et al. 2007. Identification of FAAP24, a Fanconi anemia core complex protein that interacts with FANCM. Mol Cell 25: 331-343.

Cimino GD, Gamper HB, Isaacs ST, Hearst JE. 1985. Psoralens as photoactive probes of nucleic acid structure and function: Organic chemistry, photochemistry, and biochemistry. Annu Rev Biochem 54: 1151-1193.

Cohn MA, Kowal P, Yang K, Haas W, Huang TT, Gygi SP, D'Andrea AD. 2007. A UAF1-containing multisubunit protein complex regulates the Fanconi anemia pathway. Mol Cell 28: 786-797.

Collis SJ, Barber LJ, Ward JD, Martin JS, Boulton SJ. 2006. C. elegans FANCD2 responds to replication stress and functions in interstrand cross-link repair. DNA Repair (Amst) 5: $1398-1406$
Crossan GP, van der Weyden L, Rosado IV, Langevin F, Gaillard P-HL, McIntyre RE, Gallagher F, Kettunen MI, Lewis DY, Brindle K, et al. 2011. Disruption of mouse Slx4, a regulator of structure-specific nucleases, phenocopies Fanconi anemia. Nat Genet 43: 147-152.

Cui B, Johnson SP, Bullock N, Ali-Osman F, Bigner DD, Friedman HS. 2009. Bifunctional DNA alkylator 1,3bis(2-chloroethyl)-1-nitrosourea activates the ATRChk1 pathway independently of the mismatch repair pathway. Mol Pharmacol 75: 1356-1363.

Deans AJ, West SC. 2009. FANCM connects the genome instability disorders Bloom's syndrome and Fanconi anemia. Mol Cell 36: 943-953.

Deans AJ, West SC. 2011. DNA interstrand crosslink repair and cancer. Nat Rev Cancer 11: 467-480.

dos Santos LS, Van Houten B. 2010. DNA repair database (https://dnapittcrew.upmc.com). University of Pittsburgh, Pittsburgh, PA.

Duquette ML, Zhu Q, Taylor ER, Tsay AJ, Shi LZ, Berns MW, McGowan CH. 2012. CtIP is required to initiate replication-dependent interstrand crosslink repair. PLoS Genet 8: e1003050.

Dutta S, Chowdhury G, Gates KS. 2007. Interstrand crosslinks generated by abasic sites in duplex DNA. J Am Chem Soc 129: 1852-1853.

Enoiu M, Jiricny J, Schärer OD. 2012. Repair of cisplatininduced DNA interstrand crosslinks by a replication-independent pathway involving transcription-coupled repair and translesion synthesis. Nucleic Acids Res 40: 8953-8964.

Fekairi S, Scaglione S, Chahwan C, Taylor ER, Tissier A, Coulon S, Dong MQ, Ruse C, Yates JR 3rd, Russell P, et al. 2009. Human SLX4 is a Holliday junction resolvase subunit that binds multiple DNA repair/recombination endonucleases. Cell 138: 78-89.

Fischhaber PL, Gall AS, Duncan JA, Hopkins PB. 1999. Direct demonstration in synthetic oligonucleotides that $N, N^{\prime}$-Bis(2-chloroethyl)-nitrosourea cross-links $N^{1}$ of deoxyguanosine to $N^{3}$ of deoxycytidine on opposite strands of duplex DNA. Cancer Res 59: 4363-4368.

Gan GN, Wittschieben JP, Wittschieben BO, Wood RD. 2008. DNA polymerase $\zeta$ ( $\mathrm{pol} \zeta$ ) in higher eukaryotes. Cell Res 18: 174-183.

Garaycoechea JI, Crossan GP, Langevin F, Daly M, Arends MJ, Patel KJ. 2012. Genotoxic consequences of endogenous aldehydes on mouse haematopoietic stem cell function. Nature 489: 571-575.

Gari K, Décaillet C, Delannoy M, Wu L, Constantinou A. 2008a. Remodeling of DNA replication structures by the branch point translocase FANCM. Proc Natl Acad Sci 105: 16107-16112.

Gari K, Décaillet C, Stasiak AZ, Stasiak A, Constantinou A. 2008b. The Fanconi anemia protein FANCM can promote branch migration of Holliday junctions and replication forks. Mol Cell 29: 141-148.

Grossmann KF, Ward AM, Matkovic ME, Folias AE, Moses RE. 2001. S cerevisiae has three pathways for DNA interstrand crosslink repair. Mutat Res 487: 73-83.

Guainazzi A, Schärer OD. 2010. Using synthetic DNA interstrand crosslinks to elucidate repair pathways and iden- 
tify new therapeutic targets for cancer chemotherapy. Cell Mol Life Sci 67: 3683-3697.

Guainazzi A, Campbell AJ, Angelov T, Simmerling C, Schärer OD. 2010. Synthesis and molecular modeling of a nitrogen mustard DNA interstrand crosslink. Eur J Chem 16: $12100-12103$.

Guan L, Greenberg MM. 2009. DNA interstrand cross-link formation by the 1,4-dioxobutane abasic lesion. J Am Chem Soc 131: 15225-15231.

Hanada K, Budzowska M, Modesti M, Maas A, Wyman C, Essers J, Kanaar R. 2006. The structure-specific endonuclease Mus81-Emel promotes conversion of interstrand DNA crosslinks into double-strands breaks. EMBO J 25: 4921-4932.

Hanada K, Budzowska M, Davies SL, van Drunen E, Onizawa H, Beverloo HB, Maas A, Essers J, Hickson ID, Kanaar R. 2007. The structure-specific endonuclease Mus81 contributes to replication restart by generating double-strand DNA breaks. Nat Struct Mol Biol 14: 1096-1104.

Hanlon Newell AE, Hemphill A, Akkari YM, Hejna J, Moses RE, Olson SB. 2008. Loss of homologous recombination or non-homologous end-joining leads to radial formation following DNA interstrand crosslink damage. Cytogenet Genome Res 121: 174-180.

Harris TW, Antoshechkin I, Bieri T, Blasiar D, Chan J, Chen WJ, De La Cruz N, Davis P, Duesbury M, Fang R, et al. 2010. WormBase: A comprehensive resource for nematode research. Nucleic Acids Res 38: D463-D467.

Harwood EA, Hopkins PB, Sigurdsson ST. 2000. Chemical synthesis of cross-link lesions found in nitrous acid treated DNA: A general method for the preparation of $N^{2}$-substituted 2'-deoxyguanosines. J Organ Chem 65: 2959-2964.

Hazrati A, Ramis-Castelltort M, Sarkar S, Barber LJ, Schofield CJ, Hartley JA, McHugh PJ. 2008. Human SNM1A suppresses the DNA repair defects of yeast $p s o 2$ mutants. DNA Rep 7: 230-238.

Hentschel S, Alzeer J, Angelov T, Schärer OD, Luedtke NW. 2012. Synthesis of DNA interstrand cross-links using a photocaged nucleobase. Angew Chem Int Ed Engl 51: 3466-3469.

Hlavin EM, Smeaton MB, Noronha AM, Wilds CJ, Miller PS. 2010. Cross-link structure affects replication-independent DNA interstrand cross-link repair in mammalian cells. Biochemistry 49: 3977-3988.

Ho TV, Schärer OD. 2010. Translesion DNA synthesis polymerases in DNA interstrand crosslink repair. Environ Mol Mutagen 51: 552-566.

Ho TV, Guainazzi A, Derkunt SB, Enoiu M, Schärer OD. 2011. Structure-dependent bypass of DNA interstrand crosslinks by translesion synthesis polymerases. Nucleic Acids Res 39: 7455-7464.

Huang M, D’Andrea AD. 2010. A new nuclease member of the FAN club. Nat Struct Mol Biol 17: 926-928.

Huang H, Kozekov ID, Kozekova A, Wang H, Lloyd RS, Rizzo CJ, Stone MP. 2010a. DNA cross-link induced by trans-4-hydroxynonenal. Environ Mol Mutagen 51: 625634.

Huang M, Kim JM, Shiotani B, Yang K, Zou L, D’Andrea AD. 2010b. The FANCM/FAAP24 complex is required for the DNA interstrand crosslink-induced checkpoint response. Mol Cell 39: 259-268.

Jachymczyk WJ, von Borstel RC, Mowat MR, Hastings PJ. 1981. Repair of interstrand cross-links in DNA of Saccharomyces cerevisiae requires two systems for DNA repair: the RAD3 system and the RAD51 system. Mol Gen Genet 182: 196-205.

Jamieson ER, Lippard SJ. 1999. Structure, recognition, and processing of cisplatin-DNA adducts. Chem Rev 99: 2467-2498.

Johnson KM, Price NE, Wang J, Fekry MI, Dutta S, Seiner DR, Wang Y, Gates KS. 2012a. On the formation and properties of interstrand DNA-DNA cross-links forged by reaction of an abasic site with the opposing guanine residue of 5'-CAp sequences in duplex DNA. JAm Chem Soc 135: 1015-1025.

Johnson LAA, Malayappan B, Tretyakova N, Campbell C, MacMillan ML, Wagner JE, Jacobson PA. 2012b. Formation of cyclophosphamide specific DNA adducts in hematological diseases. Pediatr Blood Cancer 58: 708-714.

Kashiyama K, Nakazawa Y, Pilz DT, Guo C, Shimada M, Sasaki K, Fawcett H, Wing JF, Lewin SO, Carr L, et al. 2013. Malfunction of nuclease ERCC1-XPF results in diverse clinical manifestations and causes Cockayne syndrome, xeroderma pigmentosum, and Fanconi anemia. Am J Hum Genet 92: 807-819.

Kim JM, Parmar K, Huang M, Weinstock DM, Ruit CA, Kutok JL, D'Andrea AD. 2009. Inactivation of murine Usp1 results in genomic instability and a Fanconi anemia phenotype. Dev Cell 16: 314-320.

Kim Y, Lach FP, Desetty R, Hanenberg H, Auerbach AD, Smogorzewska A. 2011. Mutations of the SLX4 gene in Fanconi anemia. Nat Genet 43: 142-146.

Kim H, Yang K, Dejsuphong D, D’Andrea AD. 2012. Regulation of Rev1 by the Fanconi anemia core complex. Nat Struct Mol Biol 19: 164-170.

Kim Y, Spitz GS, Veturi U, Lach FP, Auerbach AD, Smogorzewska A. 2013. Regulation of multiple DNA repair pathways by the Fanconi anemia protein SLX4. Blood 121: 54-63.

Kirchner JJ, Sigurdsson ST, Hopkins PB. 1992. Interstrand cross-linking of duplex DNA by nitrous acid: Covalent structure of the dG-to-dG cross-link at the sequence 5'-CG. J Am Chem Soc 114: 4021-4027.

Kitao H, Yamamoto K, Matsushita N, Ohzeki M, Ishiai M, Takata M. 2006. Functional interplay between BRCA2/ FancD1 and FancC in DNA repair. J Biol Chem 281: 21312-21320.

Klug AR, Harbut MB, Lloyd RS, Minko IG. 2012. Replication bypass of $N^{2}$-deoxyguanosine interstrand crosslinks by human DNA polymerases $\eta$ and $\iota$. Chem Res Toxicol 25: 755-762.

Knipscheer P, Räschle M, Smogorzewska A, Enoiu M, Ho TV, Schärer OD, Elledge SJ, Walter JC. 2009. The Fanconi anemia pathway promotes replication-dependent DNA interstrand cross-link repair. Science 326: 1698-1701.

Kratz K, Schöpf B, Kaden S, Sendoel A, Eberhard R, Lademann C, Cannavó E, Sartori AA, Hengartner MO, Jiricny J. 2010. Deficiency of FANCD2-associated nuclease KIAA1018/FAN1 sensitizes cells to interstrand crosslinking agents. Cell 142: 77-88. 


\section{Clauson et al.}

Kumari A, Minko IG, Harbut MB, Finkel SE, Goodman MF Lloyd RS. 2008. Replication bypass of interstrand crosslink intermediates by Escherichia coli DNA polymerase IV. J Biol Chem 283: 27433-27437.

Larimer FW, Perry JR, Hardigree AA. 1989. The REV1 gene of Saccharomyces cerevisiae: Isolation, sequence, and functional analysis. J Bacteriol 171: 230-237.

Lee KY, Chung KY, Koo HS. 2010. The involvement of FANCM, FANCI, and checkpoint proteins in the interstrand DNA crosslink repair pathway is conserved in C. elegans. DNA Rep 9: 374-382.

Lestini R, Duan Z, Allers T. 2010. The archaeal Xpf/Mus81/ FANCM homolog Hef and the Holliday junction resolvase $\mathrm{Hjc}$ define alternative pathways that are essential for cell viability in Haloferax volcanii. DNA Rep 9: 994-1002. duced crosslinks in nuclear and mitochondrial yeast
Leung JWC, Wang Y, Fong KW, Huen MSY, Li L, Chen J. 2012. Fanconi anemia (FA) binding protein FAAP20 stabilizes FA complementation group A (FANCA) and participates in interstrand cross-link repair. Proc Natl Acad Sci 109: 4491-4496.

Léveillé F, Ferrer M, Medhurst AL, Laghmani EH, Rooimans MA, Bier P, Steltenpool J, Titus TA, Postlethwait JH, Hoatlin ME, et al. 2006. The nuclear accumulation of the Fanconi anemia protein FANCE depends on FANCC. DNA Rep 5: 556-565.

Liu N, Lamerdin JE, Tebbs RS, Schild D, Tucker JD, Shen MR, Brookman KW, Siciliano MJ, Walter CA, Fan W, et al. 1998. XRCC2 and XRCC3, new human Rad51-family members, promote chromosome stability and protect against DNA cross-links and other damages. Mol Cell 1: 783-793.

Liu T, Ghosal G, Yuan J, Chen J, Huang J. 2010. FAN1 acts with FANCI-FANCD2 to promote DNA interstrand cross-link repair. Science 329: 693-696.

Long DT, Räschle M, Joukov V, Walter JC. 2011. Mechanism of RAD51-dependent DNA interstrand cross-link repair. Science 333: 84-87.

MacKay C, Déclais A-C, Lundin C, Agostinho A, Deans AJ, MacArtney TJ, Hofmann K, Gartner A, West SC, Helleday T, et al. 2010. Identification of KIAA1018/FAN1, a DNA repair nuclease recruited to DNA damage by monoubiquitinated FANCD2. Cell 142: 65-76.

Magana-Schwencke N, Henriques JA, Chanet R, Moustacchi E. 1982. The fate of 8-methoxypsoralen photoinDNA: comparison of wild-type and repair-deficient strains. Proc Natl Acad Sci 79: 1722-1726.

Majumdar A, Muniandy PA, Liu J, Liu JL, Liu ST, Cuenoud B, Seidman MM. 2008. Targeted gene knock in and sequence modulation mediated by a psoralen-linked triplex-forming oligonucleotide. J Biol Chem 283: 1124411252 .

Mason JM, Sekiguchi JM. 2011. Snm1B/Apollo functions in the Fanconi anemia pathway in response to DNA interstrand crosslinks. Hum Mol Genet 20: 2549-2559.

McCabe KM, Hemphill A, Akkari Y, Jakobs PM, Pauw D, Olson SB, Moses RE, Grompe M. 2008. ERCC1 is required for FANCD2 focus formation. Mol Genet Metab 95: 66-73.

McHugh PJ, Sarkar S. 2006. DNA interstrand cross-link repair in the cell cycle: A critical role for polymerase $\zeta$ in $\mathrm{G}_{1}$ phase. Cell Cycle 5: 1044-1047.
McHugh PJ, Sones WR, Hartley JA. 2000. Repair of intermediate structures produced at DNA interstrand crosslinks in Saccharomyces cerevisiae. Mol Cell Biol 20: 34253433.

McQuilton P, St Pierre SE, Thurmond J, Consortium tF. 2012. FlyBase 101-the basics of navigating FlyBase. $\mathrm{Nu}$ cleic Acids Res 40: D706-D714.

Meier B, Barber LJ, Liu Y, Shtessel L, Boulton SJ, Gartner A, Ahmed S. 2009. The MRT-1 nuclease is required for DNA crosslink repair and telomerase activity in vivo in Caenorhabditis elegans. EMBO J 28: 3549-3563.

Millard JT, Raucher S, Hopkins PB. 1990. Mechlorethamine cross-links deoxyguanosine residues at $5^{\prime}$-GNC sequences in duplex DNA fragments. J Am Chem Soc 112: 24592460.

Minko IG, Harbut MB, Kozekov ID, Kozekova A, Jakobs PM, Olson SB, Moses RE, Harris TM, Rizzo CJ, Lloyd RS. 2008a. Role for DNA polymerase $\kappa$ in the processing of $N^{2}-N^{2}$-guanine interstrand cross-links. J Biol Chem 283: $17075-17082$.

Minko IG, Yamanaka K, Kozekov ID, Kozekova A, Indiani C, O’Donnell ME, Jiang Q, Goodman MF, Rizzo CJ, Lloyd RS. 2008b. Replication bypass of the acrolein-mediated deoxyguanine DNA-peptide cross-links by DNA polymerases of the DinB family. Chem Res Toxicol 21: 1983-1990.

Misra RR, Vos JM. 1993. Defective replication of psoralen adducts detected at the gene-specific level in xeroderma pigmentosum variant cells. Mol Cell Biol 13: 1002-1012.

Mogi S, Butcher CE, Oh DH. 2008. DNA polymerase $\eta$ reduces the $\gamma$-H2AX response to psoralen interstrand crosslinks in human cells. Exp Cell Res 314: 887-895.

Moldovan G-L, Madhavan MV, Mirchandani KD, McCaffrey RM, Vinciguerra P, D'Andrea AD. 2010. DNA polymerase POLN participates in cross-link repair and homologous recombination. Mol Cell Biol 30: 1088-1096.

Mu D, Bessho T, Nechev LV, Chen DJ, Harris TM, Hearst JE, Sancar A. 2000. DNA interstrand cross-links induce futile repair synthesis in mammalian cell extracts. Mol Cell Biol 20: $2446-2454$.

Muniandy PA, Thapa D, Thazhathveetil AK, Liu S-t, Seidman MM. 2009. Repair of laser-localized DNA interstrand cross-links in $\mathrm{G}_{1}$ phase mammalian cells. J Biol Chem 284: 27908-27917.

Muñoz IM, Hain K, Déclais A-C, Gardiner M, Toh GW, Sanchez-Pulido L, Heuckmann JM, Toth R, Macartney T, Eppink B, et al. 2009. Coordination of structure-specific nucleases by human SLX4/BTBD12 is required for DNA repair. Mol Cell 35: 116-127.

Niedernhofer LJ. 2007. The Fanconi anemia signalosome anchor. Mol Cell 25: 487-490.

Niedernhofer LJ, Odijk H, Budzowska M, van Drunen E, Maas A, Theil AF, de Wit J, Jaspers NGJ, Beverloo HB, Hoeijmakers JHJ, et al. 2004. The structure-specific endonuclease Erccl-Xpf is required to resolve DNA interstrand cross-link-induced double-strand breaks. Mol Cell Biol 24: 5776-5787.

Niedzwiedz W, Mosedale G, Johnson M, Ong CY, Pace P, Patel KJ. 2004. The Fanconi anaemia gene FANCC promotes homologous recombination and error-prone DNA repair. Mol Cell 15: 607-620. 
Nijman SMB, Huang TT, Dirac AMG, Brummelkamp TR, Kerkhoven RM, D'Andrea AD, Bernards R. 2005. The deubiquitinating enzyme USP1 regulates the Fanconi anemia pathway. Mol Cell 17: 331-339.

Nishimura K, Ishiai M, Horikawa K, Fukagawa T, Takata M, Takisawa H, Kanemaki Masato T. 2012. Mcm8 and Mcm9 form a complex that functions in homologous recombination repair induced by DNA interstrand crosslinks. Mol Cell 47: 511-522.

Nojima K, Hochegger H, Saberi A, Fukushima T, Kikuchi K, Yoshimura M, Orelli BJ, Bishop DK, Hirano S, Ohzeki M, et al. 2005. Multiple repair pathways mediate tolerance to chemotherapeutic cross-linking agents in vertebrate cells. Cancer Res 65: 11704-11711.

Oestergaard VH, Langevin F, Kuiken HJ, Pace P, Niedzwiedz W, Simpson LJ, Ohzeki M, Takata M, Sale JE, Patel KJ. 2007. Deubiquitination of FANCD2 is required for DNA crosslink repair. Mol Cell 28: 798-809.

Ojwang JO, Grueneberg DA, Loechler EL. 1989. Synthesis of a duplex oligonucleotide containing a nitrogen mustard interstrand DNA-DNA cross-link. Cancer Res 49: 65296537.

Olive PL, Wlodek D, Banath JP. 1991. DNA double-strand breaks measured in individual cells subjected to gel electrophoresis. Cancer Res 51: 4671-4676.

Orelli B, McClendon TB, Tsodikov OV, Ellenberger T, Niedernhofer LJ, Schärer OD. 2010. The XPA-binding domain of ERCC1 is required for nucleotide excision repair but not other DNA repair pathways. J Biol Chem 285: 3705-3712.

Paz MM, Ladwa S, Champeil E, Liu Y, Rockwell S, Boamah EK, Bargonetti J, Callahan J, Roach J, Tomasz M. 2008 Mapping DNA adducts of mitomycin $\mathrm{C}$ and decarbamoyl mitomycin $\mathrm{C}$ in cell lines using liquid chromatography/electrospray tandem mass spectrometry. Chem Res Toxicol 21: 2370-2378.

Peng M, Litman R, Xie J, Sharma S, Brosh RM, Cantor SB. 2007. The FANCJ/MutL $\alpha$ interaction is required for correction of the cross-link response in FA-J cells. EMBO J 26: $3238-3249$.

Penkner A, Portik-Dobos Z, Tang L, Schnabel R, Novatchkova M, Jantsch V, Loidl J. 2007. A conserved function for a Caenorhabditis elegans Com1/Sae2/CtIP protein homolog in meiotic recombination. $E M B O J$ 26: 50715082 .

Phillips DH. 1996. DNA adducts in human tissues: Biomarkers of exposure to carcinogens in tobacco smoke. Environ Health Perspect 104 453-458.

Raha M, Wang G, Seidman MM, Glazer PM. 1996. Mutagenesis by third-strand-directed psoralen adducts in repair-deficient human cells: High frequency and altered spectrum in a xeroderma pigmentosum variant. Proc Natl Acad Sci 93: 2941-2946.

Räschle M, Knipscheer P, Enoiu M, Angelov T, Sun J, Griffith JD, Ellenberger TE, Schärer OD, Walter JC. 2008. Mechanism of replication-coupled DNA interstrand crosslink repair. Cell 134: 969-980.

Rink SM, Hopkins PB. 1995. A mechlorethamine-induced DNA interstrand cross-link bends duplex DNA. Biochemistry 34: 1439-1445.

Rosado IV, Niedzwiedz W, Alpi AF, Patel KJ. 2009. The Walker B motif in avian FANCM is required to limit sister chromatid exchanges but is dispensable for DNA crosslink repair. Nucleic Acids Res 37: 4360-4370.

Salewsky B, Schmiester M, Schindler D, Digweed M, Demuth I. 2012. The nuclease hSNM1B/Apollo is linked to the Fanconi anemia pathway via its interaction with FANCP/SLX4. Hum Mol Genet 21: 4948-4956.

Sarkar S, Davies AA, Ulrich HD, McHugh PJ. 2006. DNA interstrand crosslink repair during $\mathrm{G}_{1}$ involves nucleotide excision repair and DNA polymerase $\zeta$. EMBO J 25: 1285-1294.

Sartori AA, Lukas C, Coates J, Mistrik M, Fu S, Bartek J, Baer R, Lukas J, Jackson SP. 2007. Human CtIP promotes DNA end resection. Nature 450: 509-514.

Sato K, Ishiai M, Toda K, Furukoshi S, Osakabe A, Tachiwana H, Takizawa Y, Kagawa W, Kitao H, Dohmae N, et al. 2012. Histone chaperone activity of Fanconi anemia proteins, FANCD2 and FANCI, is required for DNA crosslink repair. EMBO J 31: 3524-3536.

Sengerová B, Allerston CK, Abu M, Lee SY, Hartley J, Kiakos K, Schofield CJ, Hartley JA, Gileadi O, McHugh PJ. 2012. Characterization of the human SNM1A and SNM1B Apollo DNA repair exonucleases. J Biol Chem 287: 26254-26267.

Shapiro R, Dubelman S, Feinberg AM, Crain PF, McCloskey JA. 1977. Isolation and identification of cross-linked nucleosides from nitrous acid treated deoxyribonucleic acid. J Am Chem Soc 99: 302-303.

Sharma S, Helchowski CM, Canman CE. 2013. The roles of DNA polymerase $\zeta$ and the $\mathrm{Y}$ family DNA polymerases in promoting or preventing genome instability. Mutat Res 743-744: 97-110.

Shen X, Jun S, O’Neal LE, Sonoda E, Bemark M, Sale JE, Li L. 2006. REV3 and REV1 play major roles in recombination-independent repair of DNA interstrand cross-links mediated by monoubiquitinated proliferating cell nuclear antigen (PCNA). J Biol Chem 281: 13869-13872.

Shen X, Do H, Li Y, Chung W-H, Tomasz M, de Winter JP, Xia B, Elledge SJ, Wang W, Li L. 2009a. Recruitment of Fanconi anemia and breast cancer proteins to DNA damage sites is differentially governed by replication. Mol Cell 35: 716-723.

Shen X, Do H, Li Y, Chung WH, Tomasz M, de Winter JP, Xia B, Elledge SJ, Wang W, Li L. 2009b. Recruitment of Fanconi anemia and breast cancer proteins to DNA damage sites is differentially governed by replication. Mol Cell 35: 716-723.

Sinden RR, Cole RS. 1978a. Repair of cross-linked DNA and survival of Escherichia coli treated with psoralen and light: Effects of mutations influencing genetic recombination and DNA metabolism. J Bacteriol 136: 538-547.

Sinden RR, Cole RS. 1978b. Topography and kinetics of genetic recombination in Escherichia coli treated with psoralen and light. Proc Natl Acad Sci 75: 2373-2377.

Smeaton MB, Hlavin EM, McGregor Mason T, Noronha AM, Wilds CJ, Miller PS. 2008. Distortion-dependent unhooking of interstrand cross-links in mammalian cell extracts. Biochemistry 47: 9920-9930.

Smogorzewska A, Matsuoka S, Vinciguerra P, McDonald ER 3rd, Hurov KE, Luo J, Ballif BA, Gygi SP, Hofmann K, D'Andrea AD, et al. 2007. Identification of the FANCI protein, a monoubiquitinated FANCD2 paralog required for DNA repair. Cell 129: 289-301. 


\section{Clauson et al.}

Smogorzewska A, Desetty R, Saito TT, Schlabach M, Lach FP, Sowa ME, Clark AB, Kunkel TA, Harper JW, Colaiácovo MP, et al. 2010. A genetic screen identifies FAN1, a Fanconi anemia-associated nuclease necessary for DNA interstrand crosslink repair. Mol Cell 39: 36-47.

Somyajit K, Subramanya S, Nagaraju G. 2012. Distinct roles of FANCO/RAD51C protein in DNA damage signaling and repair. J Biol Chem 287: 3366-3380.

Sonoda E, Okada T, Zhao GY, Tateishi S, Araki K, Yamaizumi M, Yagi T, Verkaik NS, van Gent DC, Takata M, et al. 2003. Multiple roles of Rev3, the catalytic subunit of pol $\zeta$ in maintaining genome stability in vertebrates. $E M B O J \mathbf{2 2}$ : 3188-3197.

Spanswick VJ, Hartley JM, Hartley JA. 2010. Measurement of DNA interstrand crosslinking in individual cells using the single cell gel electrophoresis (comet) assay. Methods Mol Biol 613: 267-282.

Stoepker C, Hain K, Schuster B, Hilhorst-Hofstee Y, Rooimans MA, Steltenpool J, Oostra AB, Eirich K, Korthof ET, Nieuwint AW, et al. 2011. SLX4, a coordinator of structure-specific endonucleases, is mutated in a new Fanconi anemia subtype. Nat Genet 43: 138-141.

Stone MP, Cho Y-J, Huang H, Kim H-Y, Kozekov ID, Kozekova A, Wang H, Minko IG, Lloyd RS, Harris TM, et al. 2008. Interstrand DNA cross-links induced by $\alpha, \beta$-unsaturated aldehydes derived from lipid peroxidation and environmental sources. Acc Chem Res 41: 793-804.

Sugahara R, Mon H, Lee JM, Kusakabe T. 2012. Monoubiquitination-dependent chromatin loading of FancD2 in silkworms, a species lacking the FA core complex. Gene 501: $180-187$.

Svendsen JM, Smogorzewska A, Sowa ME, O'Connell BC, Gygi SP, Elledge SJ, Harper JW. 2009. Mammalian BTBD12/SLX4 assembles a Holliday junction resolvase and is required for DNA repair. Cell 138: 63-77.

Thazhathveetil AK, Liu ST, Indig FE, Seidman MM. 2007. Psoralen conjugates for visualization of genomic interstrand cross-links localized by laser photoactivation. Bioconj Chem 18: 431-437.

Tiefenbach T, Junop M. 2012. Pso2 (SNM1) is a DNA structure-specific endonuclease. Nucleic Acids Res 40: 21312139.

Tomasz M. 1995. Mitomycin C: Small, fast and deadly (but very selective). Chem Biol 2: 575-579.

Trujillo JP, Mina LB, Pujol R, Bogliolo M, Andrieux J, Holder M, Schuster B, Schindler D, Surrallés J. 2012. On the role of FAN1 in Fanconi anemia. Blood 120: 86-89.

Vare D, Groth P, Carlsson R, Johansson F, Erixon K, Jenssen D. 2012. DNA interstrand crosslinks induce a potent replication block followed by formation and repair of double strand breaks in intact mammalian cells. DNA Rep 11: 976-985.

Vaz F, Hanenberg H, Schuster B, Barker K, Wiek C, Erven V, Neveling K, Endt D, Kesterton I, Autore F, et al. 2010. Mutation of the RAD51C gene in a Fanconi anemialike disorder. Nat Genet 42: 406-409.

Volker M, Moné MJ, Karmakar P, van Hoffen A, Schul W Vermeulen W, Hoeijmakers JHJ, van Driel R, van Zeeland AA, Mullenders LHF. 2001. Sequential assembly of the nucleotide excision repair factors in vivo. Mol Cell 8: 213-224.
Wang X, Peterson CA, Zheng H, Nairn RS, Legerski RJ, Li L. 2001. Involvement of nucleotide excision repair in a recombination-independent and error-prone pathway of DNA interstrand cross-link repair. Mol Cell Biol 21: 713-720.

Wang X, Kennedy RD, Ray K, Stuckert P, Ellenberger T, D'Andrea AD. 2007. Chk1-mediated phosphorylation of FANCE is required for the Fanconi anemia/BRCA pathway. Mol Cell Biol 27: 3098-3108.

Wang AT, Sengerová B, Cattell E, Inagawa T, Hartley JM, Kiakos K, Burgess-Brown NA, Swift LP, Enzlin JH, Schofield CJ, et al. 2011. Human SNM1A and XPF-ERCC1 collaborate to initiate DNA interstrand cross-link repair. Genes Dev 25: 1859-1870.

Wang Y, Leung Justin W, Jiang Y, Lowery Megan G, Do H, Vasquez Karen M, Chen J, Wang W, Li L. 2013. FANCM and FAAP24 maintain genome stability via cooperative as well as unique functions. Mol Cell 49: 997-1009.

Williams Hannah L, Gottesman Max E, Gautier J. 2012. Replication-independent repair of DNA interstrand crosslinks. Mol Cell 47: 140-147.

Wu HI, Brown JA, Dorie MJ, Lazzeroni L, Brown JM. 2004. Genome-wide identification of genes conferring resistance to the anticancer agents cisplatin, oxaliplatin, and mitomycin C. Cancer Res 64: 3940-3948.

Wu JH, Wilson JB, Wolfreys AM, Scott A, Jones NJ. 2009. Optimization of the comet assay for the sensitive detection of PUVA-induced DNA interstrand cross-links. $\mathrm{Mu}$ tagenesis 24: 173-181.

Xue Y, Li Y, Guo R, Ling C, Wang W. 2008. FANCM of the Fanconi anemia core complex is required for both monoubiquitination and DNA repair. Hum Mol Genet 17: 1641-1652.

Yamamoto KN, Kobayashi S, Tsuda M, Kurumizaka H, Takata M, Kono K, Jiricny J, Takeda S, Hirota K. 2011. Involvement of SLX4 in interstrand cross-link repair is regulated by the Fanconi anemia pathway. Proc Natl Acad Sci 108: 6492-6496.

Yamanaka K, Minko IG, Takata K-i, Kolbanovskiy A, Kozekov ID, Wood RD, Rizzo CJ, Lloyd RS. 2010. Novel enzymatic function of DNA polymerase $v$ in translesion DNA synthesis past major groove DNA-peptide and DNA-DNA cross-links. Chem Res Toxicol 23: 689695.

Yan Y, Akhter S, Zhang X, Legerski R. 2010a. The multifunctional SNM1 gene family: Not just nucleases. Future Oncol 6: 1015-1029.

Yan Z, Delannoy M, Ling C, Daee D, Osman F, Muniandy PA, Shen X, Oostra AB, Du H, Steltenpool J, et al. 2010b. A histone-fold complex and FANCM form a conserved DNA-remodeling complex to maintain genome stability. Mol Cell 37: 865-878.

Yan Z, Guo R, Paramasivam M, Shen W, Ling C, Fox D 3rd, Wang Y, Oostra AB, Kuehl J, Lee DY, et al. 2012. A ubiquitin-binding protein, FAAP20, links RNF8-mediated ubiquitination to the Fanconi anemia DNA repair network. Mol Cell 47: 61-75.

Youds JL, Barber LJ, Ward JD, Collis SJ, O’Neil NJ, Boulton SJ, Rose AM. 2008. DOG-1 is the Caenorhabditis elegans BRIP1/FANCJ homologue and functions in interstrand cross-link repair. Mol Cell Biol 28: 1470-1479. 
DNA Interstrand Cross-Link Repair

Zamble DB, Mu D, Reardon JT, Sancar A, Lippard SJ. 1996. Repair of cisplatin-DNA adducts by the mammalian excision nuclease. Biochemistry 35: 10004-10013.

Zhao J, Jain A, Iyer RR, Modrich PL, Vasquez KM. 2009. Mismatch repair and nucleotide excision repair proteins cooperate in the recognition of DNA interstrand crosslinks. Nucleic Acids Res 37: 4420-4429.

Zheng H, Wang X, Warren AJ, Legerski RJ, Nairn RS, Hamilton JW, Li L. 2003. Nucleotide excision repair- and polymerase $\eta$-mediated error-prone removal of mitomycin C interstrand cross-links. Mol Cell Biol 23: 754761.
Zhou W, Otto EA, Cluckey A, Airik R, Hurd TW, Chaki M, Diaz K, Lach FP, Bennett GR, Gee HY, et al. 2012. FAN1 mutations cause karyomegalic interstitial nephritis, linking chronic kidney failure to defective DNA damage repair. Nat Genet 44: 910-915.

Zietlow L, Smith LA, Bessho M, Bessho T. 2009. Evidence for the involvement of human DNA polymerase $\mathrm{N}$ in the repair of DNA interstrand cross-links. Biochemistry 48: 11817-11824.

Zou L, Elledge SJ. 2003. Sensing DNA damage through ATRIP recognition of RPA-ssDNA complexes. Science 300: 1542-1548. 


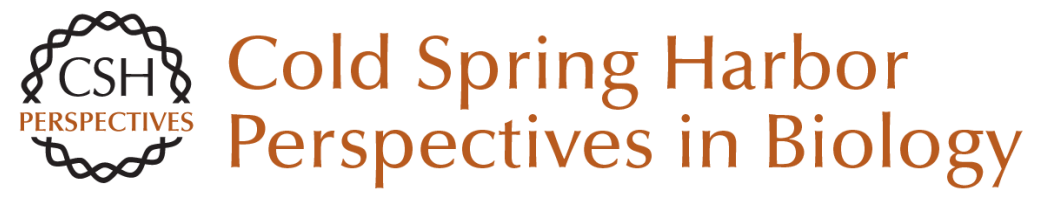

\section{Advances in Understanding the Complex Mechanisms of DNA Interstrand Cross-Link Repair}

Cheryl Clauson, Orlando D. Schärer and Laura Niedernhofer

Cold Spring Harb Perspect Biol 2013; doi: 10.1101/cshperspect.a012732

Subject Collection DNA Repair, Mutagenesis, and Other Responses to DNA Damage

DNA Repair by Reversal of DNA Damage Chengqi Yi and Chuan He

Replicating Damaged DNA in Eukaryotes Nimrat Chatterjee and Wolfram Siede

DNA Damage Sensing by the ATM and ATR

Kinases

Alexandre Maréchal and Lee Zou

Repair of Strand Breaks by Homologous

Recombination

Maria Jasin and Rodney Rothstein

Advances in Understanding the Complex

Mechanisms of DNA Interstrand Cross-Link

Repair

Cheryl Clauson, Orlando D. Schärer and Laura Niedernhofer

Ancient DNA Damage Jesse Dabney, Matthias Meyer and Svante Pääbo

DNA Damage Response: Three Levels of DNA Repair Regulation

Bianca M. Sirbu and David Cortez

Alternative Excision Repair Pathways Akira Yasui
DNA Repair by Reversal of DNA Damage Chengqi Yi and Chuan He

Translesion DNA Synthesis and Mutagenesis in

Prokaryotes

Robert P. Fuchs and Shingo Fujii

Nucleosome Dynamics as Modular Systems that Integrate DNA Damage and Repair Craig L. Peterson and Genevieve Almouzni

DNA Damage Responses in Prokaryotes:

Regulating Gene Expression, Modulating Growth

Patterns, and Manipulating Replication Forks Kenneth N. Kreuzer

Nucleotide Excision Repair in Eukaryotes Orlando D. Schärer

Biology of Extreme Radiation Resistance: The Way of Deinococcus radiodurans Anita Krisko and Miroslav Radman

Mammalian Transcription-Coupled Excision

Repair Wim Vermeulen and Maria Fousteri

DNA Repair at Telomeres: Keeping the Ends Intact

Christopher J. Webb, Yun Wu and Virginia A. Zakian

For additional articles in this collection, see http://cshperspectives.cshlp.org/cgi/collection/

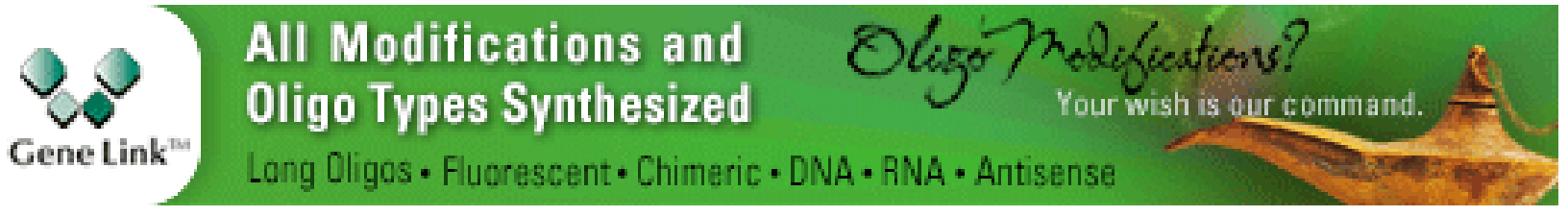

Copyright @ 2013 Cold Spring Harbor Laboratory Press; all rights reserved 
For additional articles in this collection, see http://cshperspectives.cshlp.org/cgi/collection/

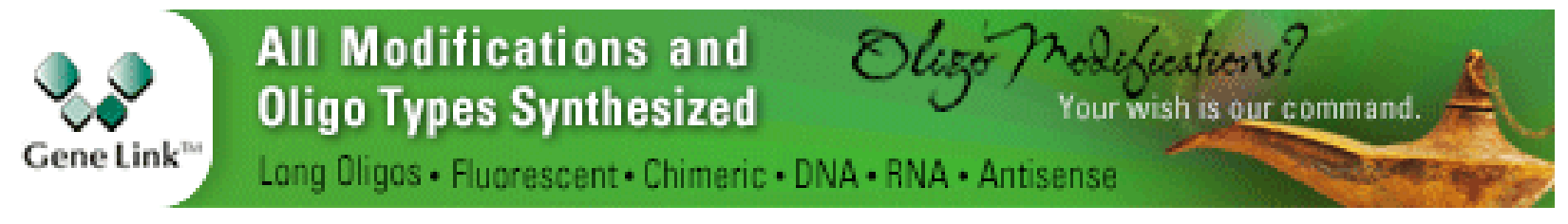

Copyright @ 2013 Cold Spring Harbor Laboratory Press; all rights reserved 